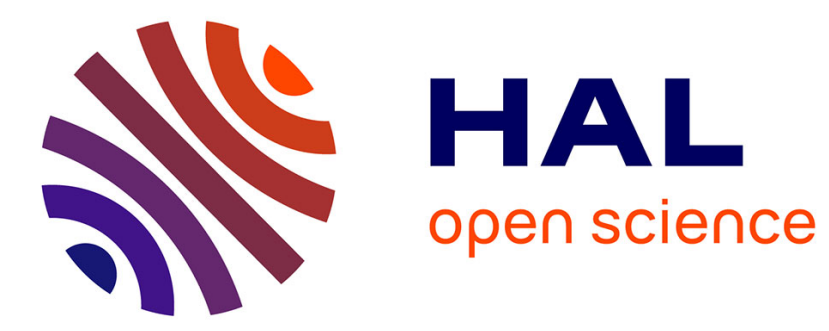

\title{
Long term mobilisation of chemical elements in tephra-rich peat (NE Iceland)
}

François de Vleeschouwer, Brigitte van Vliet-Lanoë, Nathalie Fagel

\section{To cite this version:}

François de Vleeschouwer, Brigitte van Vliet-Lanoë, Nathalie Fagel. Long term mobilisation of chemical elements in tephra-rich peat (NE Iceland). Applied Geochemistry, 2008, 23 (12), pp.3819-3839. 10.1016/j.apgeochem.2008.10.006 . insu-00338740

\section{HAL Id: insu-00338740 \\ https://hal-insu.archives-ouvertes.fr/insu-00338740}

Submitted on 8 Mar 2021

HAL is a multi-disciplinary open access archive for the deposit and dissemination of scientific research documents, whether they are published or not. The documents may come from teaching and research institutions in France or abroad, or from public or private research centers.
L'archive ouverte pluridisciplinaire $\mathbf{H A L}$, est destinée au dépôt et à la diffusion de documents scientifiques de niveau recherche, publiés ou non, émanant des établissements d'enseignement et de recherche français ou étrangers, des laboratoires publics ou privés. 


\title{
Long term mobilisation of chemical elements in tephra-rich peat (NE Iceland)
}

\author{
François De Vleeschouwer ${ }^{\mathrm{a}}$, Brigitte Van Vliët Lanoé ${ }^{\mathrm{b}, 1}$, Nathalie Fagel $^{\mathrm{a}}$ \\ ${ }^{a}$ Unité de Recherche Argiles et Paléoclimats, Université de Liège, Allée du 6 Août, B18, Sart Tilman, B-4000 Liège, Belgium \\ ${ }^{b}$ UMR 8110 CNRS Processus et Bilans des Domaines Sédimentaires, Université Sciences et des Technologies de Lille, SN5, B-59655 \\ Villeneuve d'Ascq cédex, France
}

\begin{abstract}
This paper presents geochemical profiles of a tephra-bearing minerotrophic peat column from NE-Iceland obtained using various elemental analyses of the solid phase and the pore water. The influence of tephra grain size, thickness and composition of each tephra on the peat geochemistry was investigated. Interpretations are supported by a statistical approach, in particular by autocorrelation, and by microscopy observations. Minerotrophic peat geochemistry may be strongly dependent upon post-depositional mobilization and possible leaching of elements as demonstrated by $\mathrm{Fe}$ and trace metal concentration profiles. Chemical elements, and more specifically potentially harmful metals, can be slowly leached out of volcanic falls during their weathering and re-accumulate downwards. It is emphasised that a tephra deposit can act as an active geochemical barrier, blocking downward elemental movements and leading to the formation of enriched layers. In this study, the formation of poorly amorphous Fe phases above the Hekla 3 tephra is shown. These poorly crystalline Fe phases scavenged Ni.
\end{abstract}

\section{Introduction}

Tephra is material ejected from a volcano to the atmosphere (Lowe and Hunt, 2001). Tephra can have a range of grain sizes, from plurimetric blocks to fine micrometric ash. The composition can vary between acidic $\left(\left[\mathrm{SiO}_{2}\right]>\right.$ $60 \%)$ and basic $\left(44 \%<\left[\mathrm{SiO}_{2}\right]<52 \%\right)$. Basic tephras will be generally enriched in $\mathrm{Fe}$ and $\mathrm{Mg}$. When dealing with aerial products resulting from magma projection in the atmosphere and rapid cooling, such as e.g. ignimbrites or ash falls, acidic tephras will generally be characterized by white and translucent glass shards (i.e. pumice), whereas basic ones will be darker (i.e. scoriae). Due to their grain size, the intensity of the volcanic explosion and the wind directions, tephra can be transported from very short to worldwide distances (Sparks et al., 1997). Volcanic deposits can strongly impact the surrounding environment (e.g. Holmes et al., 1999; Sadler and Grattan, 1999; Schmincke et al., 1999) in terms of immediate floral and faunal destruction (e.g. Hotes et al., 2004), and chemical changes (e.g. Haeckel et al., 2001; Flaathen and Gislason, 2007). Most of the studies dealing with the impact of volcanic falls have focused upon short time scales. For example, Flaathen and Gislason (2007) investigated the immediate impact of the 1991 and 2000 Mount Hekla eruptions in terms of major and selected trace element interaction between volcanic ash and surface waters. Few studies have dealt with the long-term impact of tephras, especially on plants and the organic environment. Research by Hotes et al. (2004) on mire vegetation in Hokkaido, Japan, showed that the principal factors affecting mire vegetation and chemistry were tephra thickness and grain size rather than tephra composition, $\mathrm{pH}$ or electrical conductivity. However, the mobilisation of metals from tephra layers deposited in peatlands has not been extensively studied, especially on millennial timescales, despite the fact that possible slow leaching of chemical elements may occur in acidic environments such as peatlands (Gislason and Oelkers, 2003; Pollard et al., 2003). In this study, by combining geochemical and micromorphological data on tephra of different composition, grain size and age, it is aimed to: (1) determine the principal factors affecting individual chemical behaviour, (2) identify possible postdepositional mobilization of chemical elements, (3) depict the possible particle-to-pore-water geochemical exchange, and mineral neo-formation, and (4) assess the influence of each tephra on the peat geochemistry over a millennial time scale. In order to achieve these objectives, results are presented from an Icelandic peat column containing several tephra deposits spanning a 4-ka period. The inorganic, major and trace element trends in the solid phase and extracted pore-waters were investigated. This geochemical study is combined with microscopy

\footnotetext{
${ }^{1}$ Present address: UMR 6538 Domaines Océaniques, Institut Universitaire Européen de la Mer, Place Nicolas Copernic, 29280 Plouzané, Bretagne, France.
} 
analyses.

\section{Site location and description}

The Vesturárdalur valley is situated near Vopnafjördur, in NE Iceland. This region is mainly composed of peatand grasslands lying on glacial deposits. The thickness of peat deposits in the Vesturárdalur valley is relatively shallow (max. $2 \mathrm{~m}$ ). The position of Iceland on the Mid-Atlantic Ridge and above a volcanic hotspot leads to intense volcanic activity. Icelandic volcanic systems have emitted products from basic to acidic composition resulting from various magma processes. The principal tephras found in the Vopnafjördur area originated from the Hekla, Veidivötn and Oraefajökull volcanic systems (e.g. Thorarinsson, 1958, 1967; Larsen and Thorarinsson, 1977; Larsen et al., 1999, 2002; Eiríksson et al., 2004). Peat- and wetlands have also been continuously affected during their growth by aeolian particles coming from inland deserts.

As a great amount of material was needed for this study, and as numerous tephra layers could make any coring very difficult, it was decided to chose an outcrop and to take samples from it. The outcrop (ICE2) was selected on the basis of its maximum thickness (ca. $1.20 \mathrm{~m}$ ). The present day peat vegetation is composed of mosses (Aulacomnium palustre), Sphagnum sp. (Sphagnum teres, Sphagnum warnstorfii), mostly Cyperaceae with some Eriophorum angustifolium and E. scheuchzeri, several Carex sp., Juncaceae (Juncus alpinoarticulatus, Juncus filiformis, Juncus bufonius), horsetail (Hippuris vulgaris) and few Graminaceae (http:// www.floraislands.is/engflora.htm). Given the vegetation dominance, the important continuous mineral input from volcanism (see below) and the $\mathrm{pH}$, this peatland can be considered to be minerotrophic.

This region has a mean annual rainfall of ca. $800 \mathrm{~mm} / \mathrm{a}$, with the lowest precipitation $(30 \mathrm{~mm} / \mathrm{month})$ during April and May and the maximum (ca. $100 \mathrm{~mm} /$ month) between July and December. The mean annual temperature of the area is $4 \cdot \mathrm{C}$ with maxima $\left(\mathrm{ca} .10^{\circ} \mathrm{C}\right.$ ) during June and August, and minima $\left(\mathrm{ca} .0^{\circ} \mathrm{C}\right.$ ) from December to April. Soil temperature is however higher than air temperature (ca. $5^{\circ} \mathrm{C}$ in winter). The peatland is mostly rainwater fed. However, (sub-) surface runoff was observed within the top $10 \mathrm{~cm}$ of the outcrop. Sporadic pore-water samples collected at various depths in the profile and directly measured using $\mathrm{pH}$ paper revealed a $\mathrm{pH}$ of ca.5.5. Although the hydrological status of the present site was not investigated in detail, it can be compared to Sub-arctic peatlands, in the absence of permafrost. The combination of low water viscosity (due to low annual temperature and snow melt) with the presence of tephra in the outcrop ensures that little vertical movement occurs. Moreover, the parent material below the peat in the investigated area is a compact lodgement till (Fig. 1), which limits the vertical percolation loss and will therefore facilitate water saturation, as also stressed for most Arctic peats by Woo and Young (2006). The snow cover in Northern Iceland is specifically unstable in relation to brief warming periods related to cyclonic conditions and to wind remobilisation during cold events (catabatic winds from the South). On N-W facing slopes, this snow cover is around $1 \mathrm{~m}$ thick (A. Gudmundsson, pers. com.), mostly insulating the ground from frost penetration. During the melting season (March to late July), the lateral seepage of melt water from the overlying snow-patches buffers the temperature close to $0{ }^{\circ} \mathrm{C}$ in the peat superficial moss-root layer, except during occasional sunny days. As the ground below is warmer $\left(\mathrm{ca} .+5.5^{\circ} \mathrm{C}\right.$ MAGT), the spring inverted thermal gradient (inverted suction) together with the low water viscosity (i.e. 1.798 centipoise at $0{ }^{\circ} \mathrm{C} ; 1.5188$ centipoise at $5{ }^{\circ} \mathrm{C}$ and 1.3077 centipoise at $10{ }^{\circ} \mathrm{C}$ ) limits the efficiency of possible downward water movement. Due to these conditions, feeding of the peat mass, even by lateral water movement is thus strongly limited. This was also supported by the limited water seepage from the deep horizons in the peat observed on the outcrop. Moreover the occurrence of a capillary barrier built by the contact between the H3 tephra and compacted peat (see Section 5.5) will promote slow lateral water migration. Although water flow rates were not measured, a maximum speed of lateral to slightly oblique drainage of $0.25-1 \mathrm{~cm} / \mathrm{s}^{-1}$ can be estimated in superficial horizons from previous published studies in other sites (Blodeau and Moore, 2002; Daniels et al., 1977). However, the flow will be slower in deeper layers primarily because of peat humification and compaction, and to a lesser extent because of blocking of tephra pores by bacterial gels and mineral neosynthesis.

\section{Sampling and preparation}

\subsection{Cutting and sub-sampling}

As peat which outcrops may be affected by air conditions, a ca. $70 \mathrm{~cm}$-deep trench was dug and cleaned, and a peat column was cut into the peat face which was not in direct contact with the air. The column was ca. $1.2 \mathrm{~m}$ in height and recorded five main tephra layers. Monoliths were cut using a stainless steel knife, wrapped in plastic film and PVC boxes $(20 \times 10 \times 7 \mathrm{~cm})$ and retrieved from the outcrop using a nylon cord. Two $\mathrm{mm}$ of external peat were removed from every monolith prior to sub-sampling to avoid any contamination. Ten-cm-long by 1 - 
$\mathrm{cm}$-thick undisturbed slices were retrieved along the side of the box samples and were impregnated with resin for thin section preparation. The remaining box profiles were cut into $1 \mathrm{~cm}$ thick samples using plastic cutters and spatulas, which were cleaned using methanol and $\mathrm{mQ}$ water after each sample, to avoid cross-contamination. Except those designed for impregnation, all samples were processed in the same way: (1) pore-water extraction and analysis; (2) solid fraction analysis.

Fig. 1: Above: map of Vopnafjördur area where ICE 2 was sampled. Below: detail of ICE 2 outcrop showing a grey gleyed ash (1), two white ashes (2 and white arrow), two oxidized black scoria layers (3 and 4). Five cryptotephras (C1-C5) were also detected on thin sections (De Vleeschouwer et al., 2008).

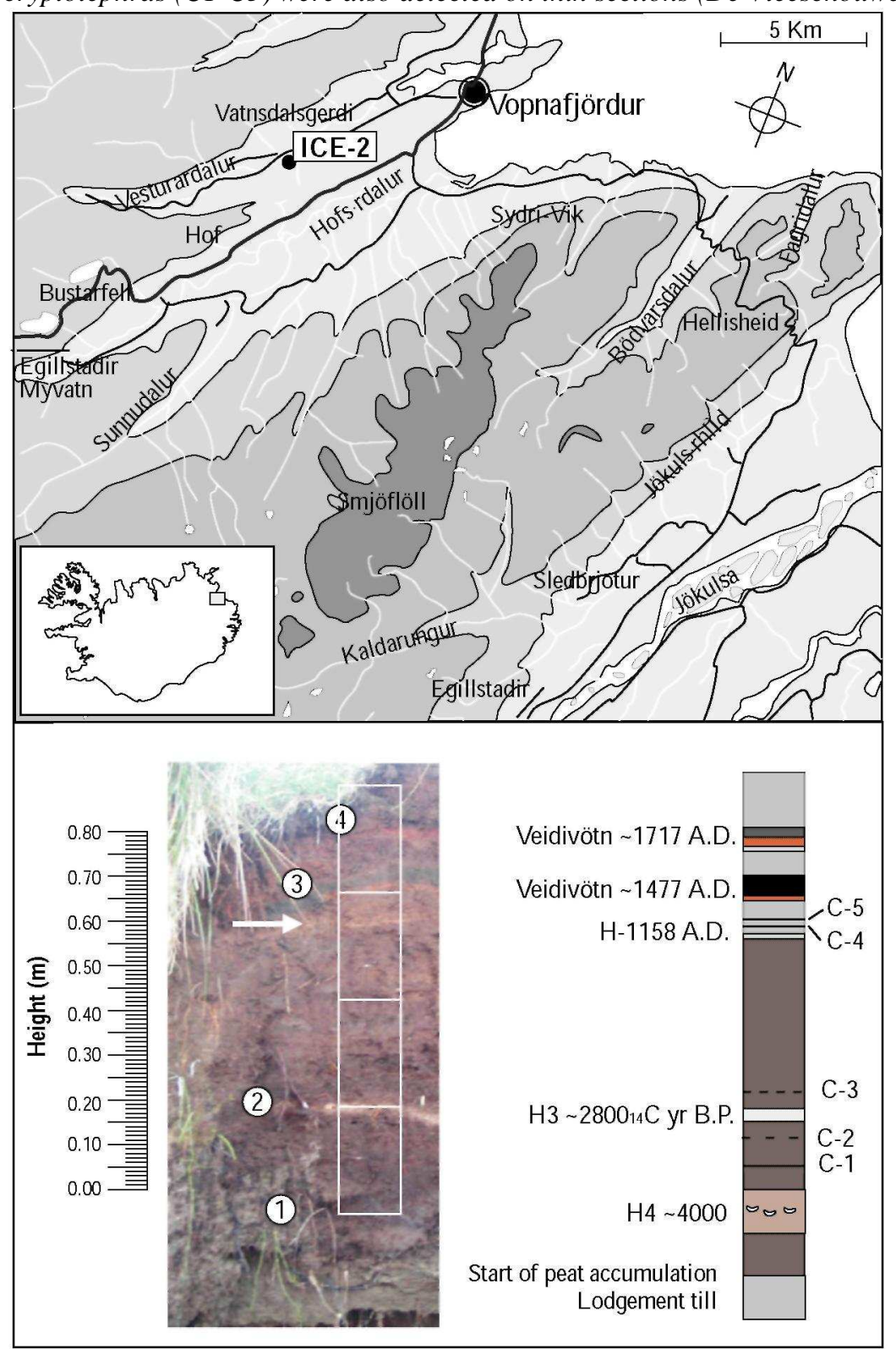

\subsection{Pore-water extraction}

Pore-water was collected from each sample (ca. $\left.50 \mathrm{~cm}^{3}\right)$ by refrigerated ultra-centrifugation $\left(15,000 \mathrm{rpm}, 10{ }^{\circ} \mathrm{C}\right)$ in PE tubes. Between each sample, tubes were cleaned using tap water followed by $\mathrm{mQ}$ water, and dried with lab clean paper. The extracted water was then directly transferred to $10 \mathrm{~mL}$ tubes and decanted. Two $\mathrm{mL}$ were subsampled for anion analysis. Then, $5 \mathrm{~mL}$ were finally sub-sampled and acidified using $\mathrm{HNO}_{3} 1 \mathrm{M}$ for cation analyses. Water samples were analysed within a week to minimize possible chemical changes. This technique 
offered the highest efficiency of pore-water extraction, and was the least time consuming when dealing with the large number of samples. However, ultra-centrifugation was critical for $\mathrm{PO}_{4}{ }^{3-}$ and to a lesser extent for $\mathrm{NO}_{3}{ }^{-}$ species as extraction was achieved in the open atmosphere (Shotyk, 1993; Steinmann and Shotyk, 1995). The extraction and cleaning processes were also critical for $\mathrm{Zn}$ contamination (J. Navez, pers. comm.). Values of $\mathrm{PO}_{4}{ }^{3-}, \mathrm{NO}_{3}{ }^{-}$and $\mathrm{Zn}$ are therefore at the very least semi-quantitative, but provided an effective guide for the relative fluctuation of these elements. It may also explain why pore-water $\mathrm{Zn}$ and $\mathrm{PO}_{4}{ }^{3-}$ measurements are frequently inaccurate.

\subsection{Solid phase preparation and treatment}

After pore-water extraction, the dried samples were crushed manually using an agate mortar and then mechanically in an agatejar pulverisette (400 rpm, $1 \mathrm{~h}$, mean grain size $\sim 70 \mu \mathrm{m})$. About $1 \mathrm{~g}$ of each peat sample was dried $\left(105^{\circ} \mathrm{C}, 12 \mathrm{~h}\right)$ and burned $\left(550{ }^{\circ} \mathrm{C}, 5 \mathrm{~h}\right)$ to estimate the loss on ignition (LOI).

In order to provide a continuous visual control of the sediment, undisturbed samples cut along the entire profile were impregnated in order to consolidate them prior to the preparation of thin sections. The method of impregnation is described in detail by Boës and Fagel (2005) and De Vleeschouwer et al. (2008). The basic steps are: (1) water removal (i.e. freeze-drying), (2) resin impregnation and (3) drying, sawing and thin-section preparation.

\section{Analytical techniques}

\subsection{X-ray fluorescence of solid phase}

For each sample, about $3.5 \mathrm{~g}$ of peat powder was pressed into pellets at $200 \mathrm{kN} / \mathrm{cm}^{2}$. All the parts of the agate mortars were cleaned using tap water, methanol and $\mathrm{mQ}$ water, and dried using pressurized air between each sample. Pellets were analysed using a XRF spectrometer equipped with a Rh primary X-ray tube (ARL 9400 XP, URPGE, University of Liège) for the following elements: $\mathrm{Si}, \mathrm{Ti}, \mathrm{AI}, \mathrm{Fe}, \mathrm{Mn}, \mathrm{Mg}, \mathrm{Ca}, \mathrm{Na}, \mathrm{K}, \mathrm{Rb}, \mathrm{Sr}, \mathrm{Ni}, \mathrm{Zn}, \mathrm{Cu}$ and $\mathrm{Pb}$.

Two different calibrations were used for the major and the trace metals, respectively. For trace metals, several international reference samples with organic- and moderate silica-matrix were used to build up elemental calibration lines. These reference samples were coals (CLB-1, NIST 1632b), lichen (BCR-482), pond sediments (NIES-2), tea leaves (NIES-7), vehicle exhaust particulates (NIES-8) and marine sediments (JSD-2, JSD-3, SGR 44). All reference samples were first analysed to estimate the mean background on XRF analysis and to calculate the mean detection limit (DL) for each element. Sediment reference samples and vehicle exhaust particles were used to increase the range of values to high levels of elements possibly encountered in recent polluted peat layers. Statistics on reference samples are given in Appendix A.

For major elements, tests using the same international reference samples did not give accurate calibration lines. Two trend lines appeared for the organic and inorganic reference samples, respectively, reflecting matrix discrepancies between these two kinds of sediments. An alternative calibration line was thus built up for major elements using commercial low concentration Sphagnum peat spiked with ultrapure major elements. First, in order to quantify the major elemental content of the commercial peat, a peat internal standard (PIS) was prepared and repeatedly measured as follows: (1) a representative amount $(\sim 200 \mathrm{~g})$ of the commercial low concentration Sphagnum peat was dried and homogenized; (2) five aliquots $(\sim 1 \mathrm{~g})$ of this peat internal standard (PIS 1-5) were ashed, acid digested $\left(\mathrm{HF}+\mathrm{HNO}_{3}\right)$ and analysed for major elements by ICP-AES (Iris Advantage, Thermo Jarrel Ash Co., MRAC Tervuren). Results are reported in Appendix B. Then, in order to reach maximum concentrations commonly encountered in peat in volcanic environments, a known amount of PIS was mixed with a known amount of the major elements, single oxides or carbonates (both ultrapure Merck quality). A part of this powder (PISAM 1, see Appendix B) was divided and diluted by 1.5, 3, 6, 12 and 24 times (PISAM 1, 2, 3, 4 and 5, respectively). For each sample (PISAM 0-5), two pellets were prepared and one aliquot was ashed, acid digested and measured by ICP-AES. The $\mathrm{SiO}_{2}$ content was estimated as: $\left[\% \mathrm{SiO}_{2}\right]=100-\sum[\%$ oxides] for both PIS and PISAM standards. Values of PISAM 0-5 were used as internal reference values to build major element calibration curves. Statistics on major elements are given in Appendix B.

\subsection{Pore-water analysis}

Cation concentrations in pore-water were measured using HR-ICP-MS (Finnigan Element 2, MRAC, Tervuren) for the following elements: Ti, AI, Fe, Mn, Mg, Ca, Na, P, Sr, Ni, Zn, Cu and Pb. Calibrations were made using 
eight artificial solutions, three for major and five for trace elements. In addition, an international reference sample (SLRS 4, riverine water) was used to assess reproducibility and accuracy. Reproducibility values are between $93 \%$ and $97 \%$. Accuracy values are below $10 \%$ for $\mathrm{Na}, \mathrm{Mg}, \mathrm{AI}, \mathrm{Ca}, \mathrm{V}, \mathrm{Cr}$ and $\mathrm{Fe}$, and between $10 \%$ and $20 \%$ for $\mathrm{Cd}, \mathrm{Pb}, \mathrm{Mn}, \mathrm{Co}, \mathrm{Ni}$ and $\mathrm{Cu}$.

Anions were measured using ion chromatography (DIO-NEX DX100, DSTE-ULB) for $\mathrm{Cl}^{-}, \mathrm{NO}_{3}{ }^{-}, \mathrm{SO}_{4}{ }^{2-}, \mathrm{PO}_{4}{ }^{3-}$ simultaneously on $500 \mathrm{IL}$ samples. The retention times of elution were $\mathrm{Cl}^{-}<\mathrm{NO}_{3}{ }^{-}<\mathrm{PO}_{4}{ }^{3-}<\mathrm{SO}_{4}{ }^{2-}$. Calibration curves were built for each day of analysis using artificial solutions (Merck quality). Reproducibility values are above $98 \%$ for $\mathrm{NO}_{3}{ }^{-} ; \mathrm{PO}_{4}{ }^{3-}$ and $\mathrm{SO}_{4}{ }^{2-}$, and between $55 \%$ and $70 \%$ for $\mathrm{Cl}^{-}$. Accuracy values are below $10 \%$ for $\mathrm{NO}_{3}{ }^{-}, \mathrm{PO}_{4}{ }^{3-}$ and $\mathrm{SO}_{4}{ }^{2-}$, and above $10 \%$ for $\mathrm{Cl}^{-}$.

\subsection{Scanning electron microscope with energy dispersive system (SEM-EDS)}

A few polished impregnated samples were $\mathrm{C}$ coated and analysed for major element content, without any resampling. The EDS used was a Quanta 200 ESEM (USTL, Lille) with a ROENTEC SDD xflash 3001 diode of 5 $\mathrm{mm}^{2}$ and a working distance of $10 \mathrm{~mm}$. Calibration was achieved using the ZAF protocol. Each elemental spectrum is compared with a spectrum obtained using an internal standard database (one spectrum per element). The precision varies with respect to atomic mass and applied voltage. Concentrations can be considered to be quantitative using point analysis, with an average error of $0.2 \%$. EDS analyses were mainly performed on glass shards, scoria and alteration products. Results are reported in Table 1.

Table 1: EDS analyses performed on shards from $H 3$ (white ash, $17.5 \mathrm{~cm}$ height), V-1477 (black scoria, $68.5 \mathrm{~cm}$ height) and poorly crystalline Fe phases. REM stands for remarks (i.e. other particular elements detected). Concentrations in wt\%.

\begin{tabular}{|c|c|c|c|c|c|c|c|c|c|c|}
\hline Section number & Sample type & $\mathrm{SiO}_{2}$ & $\mathrm{TiO}_{2}$ & $\mathbf{A l}_{2} \mathbf{O}_{3}$ & $\mathrm{FeO}_{\mathrm{t}}$ & MgO & $\mathrm{CaO}$ & $\mathrm{Na}_{2} \mathrm{O}$ & $\mathbf{K}_{2} \mathbf{O}$ & REM \\
\hline \multirow{4}{*}{ ICE2 H3 } & Glass & 70.58 & 0.34 & 15.95 & 5.47 & 0.37 & 2.79 & 2.39 & 2.11 & - \\
\hline & Alterated glass & 69.66 & 0.21 & 15.66 & 4.06 & 0.43 & 2.33 & 5.31 & 2.03 & - \\
\hline & Cracked glass & 70.42 & 0.34 & 15.58 & 3.67 & 0.41 & 2.48 & 4.53 & 2.56 & \\
\hline & Cracked glass & 74.02 & 0.27 & 15.03 & 2.51 & 0.28 & 1.67 & 3.82 & 2.40 & - \\
\hline \multirow[t]{3}{*}{ ICE2 V-1477 } & Scoria & 51.98 & 1.39 & 14.87 & 10.81 & 7.48 & 11.06 & 2.21 & 0.21 & - \\
\hline & Scoria & 50.64 & 3.33 & 14.39 & 11.92 & 6.64 & 9.30 & 3.22 & 0.56 & - \\
\hline & Alterated scoria & 51.95 & 1.13 & 4.64 & 9.18 & 16.33 & 15.91 & 0.71 & 0.15 & - \\
\hline \multirow[t]{3}{*}{ Poorly crystalline Fe phases } & High Fe & 39.1 & 0.92 & 20.3 & 27.8 & 9.58 & 1.06 & 0.47 & 0.2 & $\mathrm{SO}_{3}: 0.59$ \\
\hline & Moderate Fe & 44.6 & 7.26 & 32.9 & 12.1 & 0.75 & 1.78 & 0.59 & - & - \\
\hline & Low Fe & 14.0 & 1.88 & 16.1 & 2.77 & 0.24 & 0.99 & 0.2 & 0.19 & $\mathrm{CO}_{2}: 63.70$ \\
\hline
\end{tabular}

\subsection{Autocorrelation}

Autocorrelation is mainly used to discuss the influence of tephra falls on peat geochemistry. Numerous authors have used statistics in geochemistry. However, care should be taken when deducing interpretation from autocorrelation as the clear limit between simple visual relationship and real statistical correlation is rather vague in Earth Sciences. The interpretation of the correlation significance is variable from one author to another (e.g. Jin et al., 2006; Warren et al., 2006; Carboa et al., 2005; Price et al., 2005; Weiss et al., 2002) or even within a single article (e.g. Johnson et al., 2006; Todorova et al., 2005). "Strong" correlation is however generally accepted once $r$ is lower than $\cdot 0.8$ or higher than 0.8 .

Attention is also drawn to the fact that it is not because the correlation coefficient $r$ is elevated, that one parameter is responsible for the behaviour of another. Several parameters could also display the same behaviour, despite independent causes.

\section{Results and discussion}

The role of tephra on peat geochemistry will be discussed with regard to: (1) the ability of tephra to block and retain chemical elements and (2) possible tephra leaching. The tephra parameters which have the greatest influence on peat geochemistry will also be evaluated. 


\subsection{Tephrostratigraphy}

The stratigraphy of tephras in ICE2 was established using previous tephrostratigraphical studies (e.g. Larsen and Thorarinsson, 1977; Boygle, 1999; Larsen et al., 1999, 2002; Lacasse, 2001; Wastegård, 2002; Eiríksson et al., 2004; De Vleeschouwer et al., 2008). The tephra deposits date back to 4 ka B.P. From the base to the top of the ICE2 outcrop, the first grey gleyified ash layer (Fig. 1) is Hekla H4 tephra ( 4 ka B.P.), then in the middle part of the outcrop, the Hekla H3 white ash layer is recorded ( 2.8 ka B.P.). Microscopy observation shows that this ash displays a particularly fine grain-size $(5-20 \mu \mathrm{m})$ in the investigated outcrop. A second moderately fine grainsize $(50-200 \mu \mathrm{m})$ white ash (H-1158, A.D. 1158; Fig. 1, arrowed) is also recorded in the ICE 2 outcrop, $10 \mathrm{~cm}$ below the lowest of two sub-centimetre black scoria layers (grain size: 50-200 $\mu \mathrm{m}$ ), this latter being most likely the Veidivötn V-1477 A.D. tephra. This is confirmed by SEM analyses on single glass shards (Fig. 2). The discrepancies between the analyses and the Veidivötn field can be explained by the strong weathering of basic tephra which can make it difficult to achieve accurate analyses. The uppermost black scoria tephra (grain size: 50-100 $\mu \mathrm{m}$ ) is the Veidivötn V-1717 A.D. This tephra is also commonly found in Icelandic lake and marine sediments. Five additional cryptotephras labelled C-1-C-5 (De Vleeschouwer et al., 2008) were identified by inspection of the thin sections.

Fig. 2: Geochemical diagrams of Icelandic volcanic systems. Single grain analyses of $17.5 \mathrm{~cm}$ depth (H3) and $68.5 \mathrm{~cm}$ depth (Veidivötn 1477 A.D.) samples. H3 is represented in grey field, other tephra composition data are reported in white fields with corresponding names.
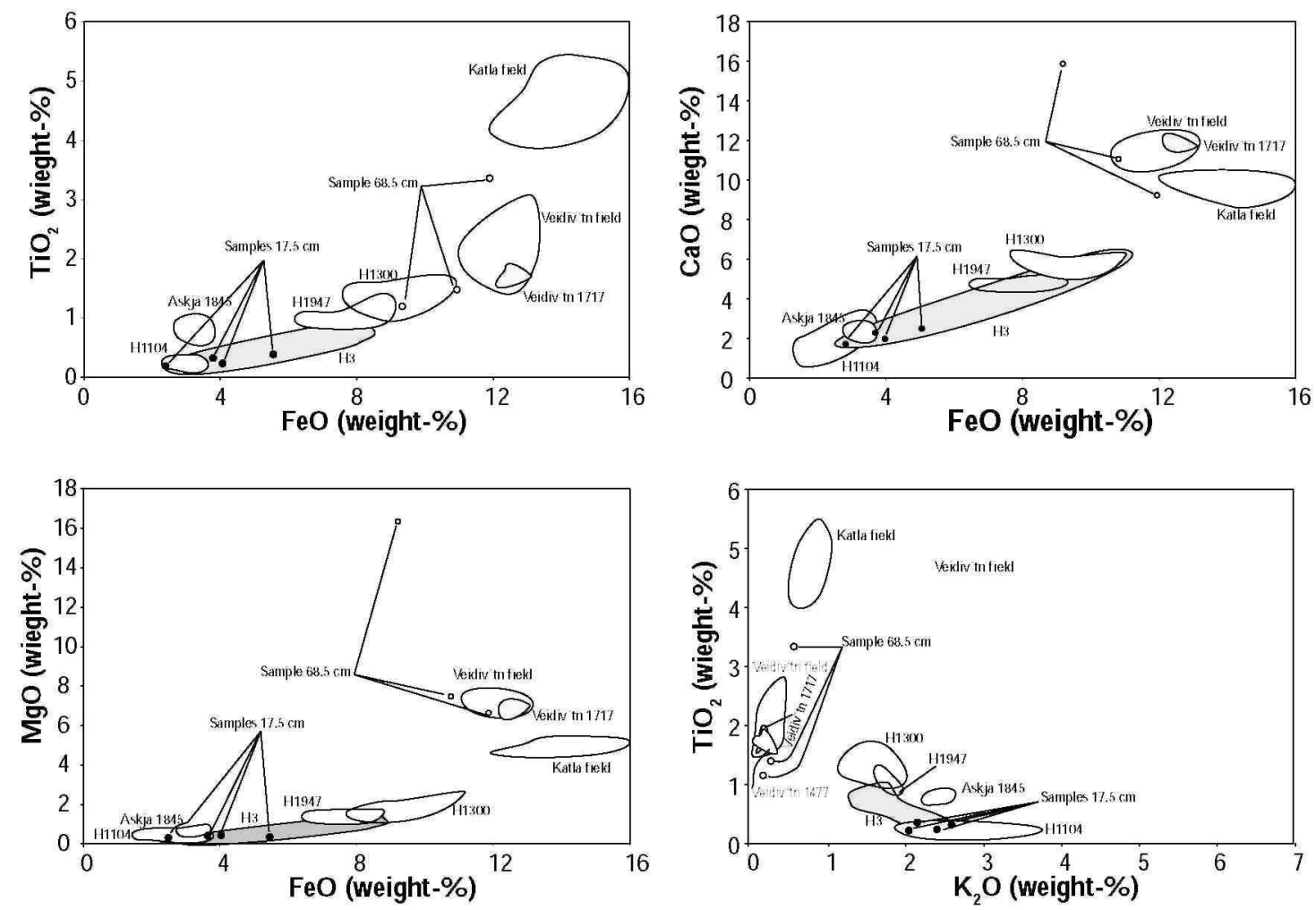

\subsection{Peat geochemistry}

Solid phase samples (Table 2) display rather high values of $\mathrm{Al}$ (median 3.4\%), Ca (median 1.1\%), Fe (median $2.0 \%$ ) and $\mathrm{Si}$ (median $7.5 \%$ ). These trends reflect the minerogenic characteristics of the peat, which receives continuous inputs of volcanic dust.

Compositional variations occur between the tephra deposits. For example, in H3, there are enrichments of $\mathrm{Si}$ and $\mathrm{Al}$ and depletion of $\mathrm{Ca}$ and $\mathrm{Fe}$. Potassium displays low concentrations $(<0.1 \%)$ except in and around the $\mathrm{H} 3$ ash, where concentrations are significantly higher, reaching $0.4 \%$ (Fig. 3). Magnesium concentrations are stable 
around $0.4 \%$, except in the two V-1477 and V-1717 scoriae layers, where this element is slightly enriched. Manganese and $\mathrm{Na}$ are below the detection limit (respectively, $0.04 \%$ and $0.4 \%$ ). Trace metals have moderately high concentrations (median $\mathrm{Cu}=4.7 \mathrm{mg} / \mathrm{kg}$, median $\mathrm{Ni}=33.5 \mathrm{mg} / \mathrm{kg}$, median $\mathrm{Zn}=51.8 \mathrm{mg} / \mathrm{kg}$ ), except $\mathrm{Pb}$, which is always below the detection limit (i.e. $<7.2 \mathrm{mg} / \mathrm{kg}$ ). Rubidium and $\mathrm{Sr}$ show a strong increase in the $\mathrm{H} 3$ tephra compared to the peat layersjust below and above it. Nickel and Zn also show an increase in concentration above the $\mathrm{H} 3$ tephra deposit. Aluminium and $\mathrm{Fe}$ in pore-water display low concentrations, with respective median values of 97 and $147 \mu \mathrm{g} / \mathrm{kg}$, although roughly peaking around the V-1477 and V-1717 scoria layer (Table 3). Calcium, $\mathrm{Na}$ and $\mathrm{Mg}$ concentrations in pore-water are much higher with median values of 17.7, 14.2, and $9.2 \mathrm{mg} / \mathrm{kg}$, respectively. Titanium ${ }_{\mathrm{pw}}$ and $\mathrm{Cu}_{\mathrm{pw}}$ roughly follow their respective solid phase profile, but peakjust under the V-1477 scoria. Copper $_{\mathrm{pw}}$ also peaks under the V-1717 tephra. Strontium pw $_{\text {displays a flat }}$ profile, except in the uppermost parts where peaks occur just under the V-1477 and V-1717 tephra deposits.

\subsection{Tephra leaching and metal release - a slow reaction}

Observation of thin sections revealed alteration films around glass shards (see also De Vleeschouwer et al., 2008). However, no significant elemental leaching was found below the tephra layers, except slight leaching above V1477 and V1717 (Fig. 3). The mechanisms responsible for tephra leaching in waterlogged sediments have been abundantly studied (e.g. Wolff-Boenisch et al., 2004a,b; Pollard et al., 2003; Techer et al., 2001; Oelkers, 2001; Thorseth et al., 1995; Hodder et al., 1991). Glass shard dissolution depends first upon the glass composition. Silica structures in basaltic glass are less organized than in rhyolitic glass, leading to various dissolution rates. Wolff-Boenisch et al. (2004a,b) deduced the relationship between the lifetime of an idealized 1-mm-thick layer composed of 1-mm radius natural glass spheres and their silica content at far from equilibrium conditions. Such small tephras may take up to 4 ka to fully dissolve. Other parameters such as Eh-pH conditions, formation of alteration films at the surface of the glass shards (which prevent dissolution), and bacterial activities can also play a role. Among those, alteration films around grains play an important role in the blocking of elemental diffusion from the glass shard to the sediment (Techer et al., 2001).

A rough calculation of the quantity of chemical species a tephra will release can be performed, by estimating the difference between the metal concentration in fresh glass shards (from the literature) and the actual metal concentration in the tephra contained in the peat column normalized to the age of the tephra (see Table 4A). However, some elements such as $\mathrm{Na}$ have been leached out to below the detection limit, and leaching rates can thus not be calculated. The calculated release rate of Fe is the second most important (ca. $9 \mathrm{mg} \mathrm{kg}^{-1} \mathrm{a}^{-1}$ ) after Si (ca. $47 \mathrm{mg} \mathrm{kg}^{-1} \mathrm{a}^{-1}$ ). The following elements leached out are cations such as Ca (ca. $5 \mathrm{mg} \mathrm{kg}^{-1} \mathrm{a}^{-1}$ ), $\mathrm{K}$ (ca. $1 \mathrm{mg}$ $\mathrm{kg}^{-1} \mathrm{a}^{-1}$ ) and $\mathrm{Mg}$ (ca. $0.6 \mathrm{mg} \mathrm{kg}^{-1} \mathrm{a}^{-1}$ ). These values are much higher than the values found by Wolff-Boenisch et al. (2004a) who found respective release rates of ca. $0.041 \mathrm{mg} \mathrm{k}^{-1} \mathrm{a}^{-1}, 0.024 \mathrm{mg} \mathrm{kg}^{-1} \mathrm{a}^{-1}, 0.019 \mathrm{mg} \mathrm{kg}^{-1} \mathrm{a}^{-1}$ and $0.003 \mathrm{mg} \mathrm{kg}^{-1} \mathrm{a}^{-1}$ for $\mathrm{Fe}, \mathrm{Ca}, \mathrm{K}$ and $\mathrm{Mg}$, respectively (re-calculated from Fig. 7 of Wolff-Boenisch et al., 2004a, using a glass density of $2.42 \mathrm{~g} \mathrm{~cm}^{-3}$ and a $\mathrm{SiO}_{2}$ content of $66 \%$ found in the outcrop at $16.5 \mathrm{~cm}$ height). These discrepancies are due to the fact that: (1) tephra deposits were sampled together with the peat and (2) the bacterial effect and protective films around the glass shards (which are expected to decrease the dissolution rates) were not taken into account.

Table 2: Concentrations in peat solid phase samples of ICE 2 peat outcrop measured by XRF (URPGE, ULg). DL: under the detection limit.

\begin{tabular}{|c|c|c|c|c|c|c|c|c|c|c|c|c|}
\hline $\begin{array}{l}\text { Height } \\
(\mathrm{cm})\end{array}$ & $\mathrm{Al}(\%)$ & $\mathrm{Ca}(\%)$ & $\mathrm{Fe}(\%)$ & $\mathrm{K}(\%)$ & $\operatorname{Mg}(\%)$ & $\mathrm{Si}(\%)$ & $\mathrm{Ti}(\%)$ & $\begin{array}{l}\mathrm{Cu} \\
(\mathrm{mg} / \mathrm{kg})\end{array}$ & $\begin{array}{l}\mathrm{Rb} \\
(\mathrm{mg} / \mathrm{kg})\end{array}$ & $\begin{array}{l}\mathrm{Sr} \\
(\mathrm{mg} / \mathrm{kg})\end{array}$ & $\begin{array}{l}\mathrm{Ni} \\
(\mathrm{mg} / \mathrm{kg})\end{array}$ & $\begin{array}{l}\mathrm{Zn} \\
(\mathrm{mg} / \mathrm{kg})\end{array}$ \\
\hline 0.5 & 2.41 & 1.13 & 1.16 & DL & 0.27 & 4.84 & 0.26 & 1.52 & 4.67 & 60.34 & 24.66 & 17.61 \\
\hline 1.5 & 2.12 & 1.09 & 1.15 & DL & 0.27 & 4.68 & 0.24 & 1.18 & 4.87 & 61.07 & 20.55 & 12.65 \\
\hline 2.5 & 1.99 & 1.07 & 0.99 & DL & 0.26 & 4.50 & 0.24 & DL & 5.03 & 58.88 & 21.09 & 10.32 \\
\hline 3.5 & 2.01 & 1.12 & 1.21 & DL & 0.27 & 4.88 & 0.24 & 1.09 & 4.46 & 56.97 & 21.35 & 11.53 \\
\hline 4.5 & 1.91 & 1.11 & 1.37 & DL & 0.27 & 5.04 & 0.24 & DL & 4.77 & 52.97 & 21.28 & 10.49 \\
\hline 5.5 & 1.89 & 1.04 & 1.37 & DL & 0.25 & 4.80 & DL & DL & 4.45 & 48.14 & 22.97 & 11.51 \\
\hline 6.5 & 2.03 & 1.02 & 1.51 & DL & 0.25 & 5.06 & DL & DL & 4.29 & 45.18 & 23.58 & 11.76 \\
\hline 7.5 & 2.21 & 0.96 & 1.81 & DL & 0.23 & 5.26 & DL & DL & 4.46 & 46.85 & 25.44 & 15.32 \\
\hline 8.5 & 2.18 & 0.95 & 2.15 & DL & 0.23 & 4.88 & DL & 1.09 & 4.63 & 44.03 & 27.25 & 22.34 \\
\hline 9.5 & 2.31 & 0.97 & 2.22 & DL & 0.24 & 4.97 & DL & 1.12 & 3.81 & 43.77 & 25.81 & 25.53 \\
\hline 10.5 & 2.13 & 0.97 & 2.39 & DL & 0.24 & 4.64 & DL & 1.62 & 5.82 & 47.39 & 28.16 & 32.80 \\
\hline 11.5 & 2.20 & 1.00 & 2.43 & DL & 0.25 & 4.69 & DL & 1.77 & 5.58 & 50.25 & 29.83 & 30.82 \\
\hline 12.5 & 2.09 & 1.00 & 2.26 & DL & 0.25 & 4.48 & DL & 1.59 & 5.51 & 50.65 & 32.88 & 31.06 \\
\hline
\end{tabular}




\begin{tabular}{|c|c|c|c|c|c|c|c|c|c|c|c|c|}
\hline 13.5 & 2.24 & 0.93 & 1.89 & 0.09 & 0.22 & 5.55 & DL & 1.39 & 6.90 & 48.89 & 32.94 & 27.87 \\
\hline 14.5 & 3.24 & 0.70 & 1.40 & 0.28 & 0.17 & 9.71 & DL & DL & 17.37 & 84.73 & 28.68 & 37.98 \\
\hline 15.5 & 3.44 & 0.64 & 1.22 & 0.33 & 0.15 & 10.70 & DL & DL & 20.37 & 92.82 & 25.53 & 38.46 \\
\hline 16.5 & 3.85 & 0.57 & 1.22 & 0.39 & 0.13 & 12.13 & DL & DL & 25.83 & 110.37 & 25.88 & 44.34 \\
\hline 17.5 & 4.04 & 0.56 & 1.30 & 0.41 & 0.13 & 12.51 & DL & DL & 27.76 & 119.83 & 25.28 & 51.45 \\
\hline 18.5 & 3.79 & 0.58 & 1.41 & 0.36 & 0.14 & 11.21 & DL & DL & 24.22 & 104.15 & 31.72 & 51.63 \\
\hline 19.5 & 4.01 & 0.59 & 1.49 & 0.37 & 0.15 & 11.80 & DL & DL & 25.38 & 111.23 & 30.40 & 58.95 \\
\hline 20.5 & 3.44 & 0.73 & 1.81 & 0.25 & 0.20 & 8.95 & DL & 1.35 & 16.67 & 84.08 & 46.85 & 67.45 \\
\hline 21.5 & 3.11 & 0.90 & 2.17 & 0.15 & 0.24 & 7.38 & DL & 2.54 & 10.21 & 68.78 & 55.23 & 63.96 \\
\hline 22.5 & 2.77 & 0.90 & 2.27 & 0.08 & 0.24 & 6.19 & DL & 3.29 & 7.22 & 57.51 & 64.23 & 64.30 \\
\hline 23.5 & 2.51 & 1.00 & 2.36 & 0.04 & 0.25 & 5.07 & DL & 3.36 & 5.68 & 51.26 & 73.26 & 52.42 \\
\hline 24.5 & 2.71 & 1.02 & 2.67 & DL & 0.27 & 5.18 & 0.30 & 4.23 & 6.41 & 64.34 & 78.75 & 65.34 \\
\hline 25.5 & 2.17 & 1.05 & 2.69 & DL & 0.24 & 3.43 & 0.27 & 4.31 & 4.85 & 47.84 & 64.71 & 42.13 \\
\hline 26.5 & 2.33 & 0.96 & 2.89 & DL & 0.24 & 4.06 & 0.26 & 5.23 & 5.27 & 42.66 & 68.16 & 47.77 \\
\hline 27.5 & 2.61 & 0.95 & 2.82 & DL & 0.26 & 4.69 & 0.26 & 5.44 & 5.49 & 47.82 & 65.36 & 53.37 \\
\hline 28.5 & 3.32 & 0.98 & 2.07 & DL & 0.29 & 5.68 & 0.28 & 5.26 & 5.65 & 62.22 & 44.33 & 43.83 \\
\hline 29.5 & 3.36 & 0.98 & 2.00 & DL & 0.29 & 5.51 & 0.31 & 5.44 & 5.85 & 61.68 & 40.99 & 39.84 \\
\hline 32.5 & 4.04 & 1.00 & 1.51 & 0.04 & 0.30 & 5.91 & 0.49 & 4.63 & 6.05 & 81.22 & 39.49 & 45.54 \\
\hline 33.5 & 4.17 & 1.07 & 1.43 & 0.04 & 0.34 & 6.22 & 0.47 & 4.67 & 6.51 & 82.82 & 38.20 & 40.29 \\
\hline 34.5 & 4.20 & 1.10 & 1.37 & 0.04 & 0.36 & 6.28 & 0.42 & 4.69 & 5.75 & 80.90 & 34.85 & 39.43 \\
\hline 35.5 & 3.94 & 1.09 & 1.27 & 0.05 & 0.35 & 6.42 & 0.38 & 4.21 & 6.98 & 80.65 & 35.79 & 41.64 \\
\hline 36.5 & 4.23 & 1.14 & 1.36 & 0.05 & 0.34 & 7.00 & 0.42 & 4.50 & 6.59 & 77.34 & 32.33 & 42.61 \\
\hline 37.5 & 4.23 & 1.18 & 1.40 & 0.05 & 0.37 & 7.08 & 0.40 & 4.31 & 6.69 & 77.44 & 34.90 & 47.09 \\
\hline 39.0 & 3.95 & 1.18 & 1.44 & 0.05 & 0.37 & 6.96 & 0.37 & 4.29 & 6.59 & 74.21 & 32.07 & 47.98 \\
\hline 40.5 & 3.13 & 1.13 & 1.56 & 0.05 & 0.31 & 6.18 & 0.29 & 3.13 & 6.47 & 70.64 & 27.29 & 50.73 \\
\hline 41.5 & 3.13 & 1.03 & 1.52 & 0.05 & 0.31 & 5.66 & 0.28 & 3.80 & 7.38 & 85.34 & 31.01 & 58.58 \\
\hline 42.5 & 3.94 & 1.25 & 1.85 & 0.05 & 0.39 & 6.99 & 0.31 & 4.62 & 7.35 & 96.52 & 34.39 & 62.87 \\
\hline 43.5 & 3.75 & 1.21 & 1.90 & 0.04 & 0.39 & 7.55 & 0.29 & 4.90 & 6.80 & 86.10 & 33.58 & 60.95 \\
\hline 44.5 & 3.35 & 1.10 & 1.88 & DL & 0.32 & 8.08 & 0.25 & 4.94 & 7.10 & 78.46 & 32.60 & 56.16 \\
\hline 45.5 & 3.21 & 1.10 & 1.98 & 0.04 & 0.34 & 9.48 & 0.25 & 4.83 & 6.63 & 79.09 & 32.09 & 49.39 \\
\hline 46.5 & 3.16 & 1.09 & 2.32 & 0.04 & 0.35 & 9.47 & 0.25 & 4.46 & 8.22 & 83.36 & 34.89 & 53.29 \\
\hline 47.5 & 3.14 & 1.00 & 2.29 & DL & 0.28 & 9.30 & 0.27 & 4.50 & 7.18 & 80.55 & 33.38 & 54.60 \\
\hline 48.5 & 3.45 & 1.10 & 2.12 & 0.04 & 0.34 & 8.78 & 0.30 & 4.65 & 8.24 & 98.76 & 35.80 & 58.21 \\
\hline 49.5 & 3.71 & 1.25 & 1.73 & 0.05 & 0.43 & 8.27 & 0.34 & 4.68 & 8.14 & 113.00 & 38.79 & 62.06 \\
\hline 50.5 & 3.66 & 1.26 & 1.58 & 0.05 & 0.41 & 8.38 & 0.31 & 5.00 & 8.51 & 104.98 & 39.55 & 58.25 \\
\hline 51.5 & 3.86 & 1.23 & 1.45 & 0.05 & 0.40 & 8.15 & 0.34 & 5.96 & 7.88 & 103.42 & 41.63 & 56.47 \\
\hline 52.5 & 4.29 & 1.24 & 1.54 & 0.06 & 0.41 & 8.42 & 0.45 & 5.45 & 8.28 & 124.47 & 43.13 & 70.44 \\
\hline 53.5 & 4.49 & 1.22 & 1.55 & 0.07 & 0.41 & 8.19 & 0.52 & 5.09 & 8.78 & 139.70 & 39.68 & 79.28 \\
\hline 54.5 & 4.85 & 1.18 & 1.59 & 0.06 & 0.39 & 8.24 & 0.54 & 5.24 & 9.31 & 137.21 & 35.26 & 81.48 \\
\hline 55.5 & 4.28 & 1.08 & 1.99 & 0.05 & 0.35 & 8.71 & 0.38 & 5.82 & 8.47 & 93.21 & 32.68 & 51.96 \\
\hline 56.5 & 4.19 & 0.97 & 2.62 & 0.04 & 0.38 & 11.21 & 0.34 & 5.74 & 6.90 & 75.37 & 27.41 & 50.07 \\
\hline 57.5 & 4.07 & 0.72 & 2.86 & DL & 0.30 & 12.17 & 0.33 & 4.00 & 7.50 & 64.70 & 21.87 & 50.33 \\
\hline 58.5 & 3.66 & 0.72 & 2.59 & 0.04 & 0.27 & 12.04 & 0.28 & DL & DL & $\mathrm{DL}$ & DL & $\mathrm{DL}$ \\
\hline 59.5 & 4.08 & 1.11 & 2.56 & 0.08 & 0.37 & 11.07 & 0.29 & DL & DL & $\mathrm{DL}$ & DL & DL \\
\hline 60.5 & 3.48 & 0.98 & 2.30 & 0.09 & 0.32 & 9.79 & 0.29 & 4.45 & 10.70 & 105.06 & 29.54 & 53.77 \\
\hline 61.5 & 3.65 & 0.90 & 2.60 & 0.06 & 0.28 & 9.12 & 0.32 & 4.77 & 9.01 & 87.87 & 27.98 & 67.48 \\
\hline 62.5 & 4.26 & 0.97 & 1.90 & 0.07 & 0.32 & 9.27 & 0.36 & 4.68 & 10.27 & 106.91 & 31.32 & 81.81 \\
\hline 63.5 & 4.32 & 1.04 & 1.79 & 0.08 & 0.35 & 9.25 & 0.37 & 4.73 & 10.25 & 113.67 & 31.88 & 82.23 \\
\hline 64.5 & 3.68 & 0.97 & 2.83 & 0.08 & 0.31 & 8.03 & 0.31 & 6.37 & 10.62 & 93.79 & 32.76 & 80.36 \\
\hline 65.5 & 2.63 & 1.02 & 4.20 & 0.06 & 0.28 & 7.53 & 0.25 & 5.54 & 10.93 & 97.92 & 38.56 & 63.64 \\
\hline 66.5 & 3.08 & 1.32 & 2.65 & 0.06 & 0.49 & 8.56 & 0.24 & 6.30 & 10.16 & 114.13 & 37.27 & 57.90 \\
\hline 69.5 & 3.97 & 1.58 & 2.05 & 0.07 & 0.69 & 8.99 & 0.26 & 6.87 & 10.94 & 139.55 & 43.69 & 62.14 \\
\hline 70.5 & 3.24 & 1.32 & 2.17 & 0.06 & 0.42 & 6.95 & 0.26 & 5.97 & 9.85 & 120.92 & 35.40 & 53.10 \\
\hline 71.5 & 3.53 & 1.31 & 2.09 & 0.07 & 0.46 & 7.83 & 0.29 & 4.87 & 9.72 & 121.52 & 36.74 & 57.40 \\
\hline 72.5 & 3.45 & 1.37 & 2.24 & 0.07 & 0.46 & 7.65 & 0.29 & 4.81 & 9.81 & 123.75 & 35.67 & 56.48 \\
\hline 73.5 & 3.02 & 1.24 & 2.56 & 0.07 & 0.41 & 7.75 & 0.25 & 4.18 & 9.64 & 111.92 & 33.50 & 52.53 \\
\hline 74.5 & 2.91 & 1.25 & 2.48 & 0.06 & 0.38 & 7.43 & 0.26 & 4.04 & 9.29 & 108.92 & 34.14 & 46.94 \\
\hline 75.5 & 2.94 & 1.28 & 2.44 & 0.06 & 0.40 & 6.72 & 0.25 & 4.38 & 9.26 & 109.20 & 34.68 & 47.37 \\
\hline 76.5 & 3.27 & 1.36 & 2.35 & 0.07 & 0.46 & 7.29 & 0.27 & 4.65 & 9.29 & 120.58 & 36.20 & 52.99 \\
\hline 77.5 & 3.86 & 1.34 & 2.59 & 0.07 & 0.51 & 8.27 & 0.27 & 10.13 & 9.75 & 103.15 & 37.71 & 69.59 \\
\hline
\end{tabular}




\subsection{Tephra leaching or simple mix - the case of H1158 and Veidivötn tephras}

Below H1158, Ca, Sr, Ni and $\mathrm{K}$ are correlated (Appendix E). Nickel is also positively correlated with Zn. Copper is positively correlated with $\mathrm{Rb}, \mathrm{Ni}$ and, to a lesser extent, with $\mathrm{Sr}$. A careful inspection of thin sections showed that the only feature causing this correlation is a transition from a peat with its own chemical composition to H1158. The progressive mix of particles from the peat (enriched in $\mathrm{Ti}, \mathrm{Ca}, \mathrm{Al}, \mathrm{Sr}$ and $\mathrm{Zn}$ ) to $\mathrm{H} 1158$ (depleted in $\mathrm{Ti}, \mathrm{Ca}, \mathrm{Al}, \mathrm{Sr}$ and $\mathrm{Zn}$ relative to the peat) provokes simultaneous changes in the chemical profiles. In comparison, $\mathrm{Fe}$ and $\mathrm{Si}$ concentrations increase below the tephra and are strongly negatively correlated with the other elements, as these two elements are enriched in mineral phases from the tephra. Moreover, the maximum $\mathrm{Ti}$ concentration is in the peat below H1158. Titanium is generally considered immobile in soil profiles, which would suggest that the peak in concentrations (i.e. $\mathrm{Ti}, \mathrm{Ca}, \mathrm{Al}, \mathrm{Sr}, \mathrm{Zn}$ ) is not the result of the leaching of elements from H1158. In pore-waters, two groups of elements are apparent. On one hand, $\mathrm{Al}_{\mathrm{pw}}, \mathrm{Fe}_{\mathrm{pw}}, \mathrm{Ti}_{\mathrm{pw}}$ and to a lesser extent $\mathrm{Cu}_{\mathrm{pw}}$ are correlated positively. These are enriched within $\mathrm{H} 1158$, suggesting partial cation leaching within the tephra. However, no post-depositional mobilisation can be found. This phenomenon is also found in Veidivötn A.D. 1477. Elemental mapping of V1477 also shows leaching of tephra and the formation of amorphous particles enriched in Fe and AI, compared to Si (Fig. 4).

\subsection{Tephra as an active barrier - the case of H3 tephra}

The study site is a stratified peat deposit formed on a gentle slope and the water flow is expected to be oblique. Nevertheless, the presence of tephra layers will promote the specific surface of their vacuoles to behave as a capillary barrier, impeding downward transmission of water, mostly by single capillary forces, and promoting water flow at its upper contact with the peat. Open vacuoles in the tephra also play a role as a specific microbial biotope with very slow water exchange, facilitating the weathering of basaltic grains. As no real true flow exists in a tephra layer, this pathway is slowly blocked by bacterial production, increasing the mechanical role of the capillary barrier. For this reason the development of bacterial gels with high exchange surface on the tephra favours the adsorption of metallic cations. Under these conditions, weathering of volcanic dust in the upper peat and on the surface slope due to the production of humic acids and bacterial production will lead to the release of cations, especially Fe from basaltic glasses.

In the peat column shown here, Fe is often enriched above and below tephra layers (Fig. 3). This is particularly the case above H3 (between 24.5 and $27.5 \mathrm{~cm}$ height), despite Hekla H-3 being a low to moderate Fe tephra compared to basic tephra like Veidivötn. The increase in metal content can be estimated by comparing the metal content in the peak (between 24.5 and $27.5 \mathrm{~cm}$ height) and its counterpart in the low concentration peat, which is assumed to represent the sediment which is less influenced by metal accumulation. Such layers are found between 32.5 and $40.5 \mathrm{~cm}$ height, where most of the chemical species analyzed display low values or flat profiles. Calculations show that the Fe content is enriched by $100 \%$ just above H3 (Table 4B), while other elements are depleted (enrichment factor $<0 \%$ ) or display no significant enrichment. Based on microscopic observation, the primary features found in thin section at around $25 \mathrm{~cm}$ height are oxyhydroxide patches (Fig. 5). Iron oxyhydroxides are highly mobile and common features in organic sediments under slightly acidic (pH 5-6) conditions (Cornell et al., 1989), which are the typical minerotrophic peat water conditions. These oxyhydroxides are commonly goethite in soils that have restricted drainage and form orange to light brown patches. Flaathen and Gislason (2007) also identified rapid amorphous FeOOH saturation in surface waters polluted by ash falls in Iceland. In addition a strong link between Fe and LOI implies that the poorly crystalline phase containing Fe could be partly organic. Iron hydroxides form by Eh modification due to the consumption of $\mathrm{Fe}$ (II) chelates by bacteria and local $\mathrm{pH}$ increases due to the weathering of basaltic glass. Moreover, because of the behaviour of the capillary barrier, the lowermost interface is aerated/oxidized. For this reason, the solubility of Fe decreases in favour of more oxidized forms. Another explanation could be that organic matter (i.e. mucus on cyanobacteria filaments) is adsorbing superficial Fe oxyhydroxide as observed by Soulier (1995). This adsorption of poorly crystalline Fe phases was also identified by Glasauer et al. (2002).

Nickel is also strongly enriched (91\%), similar to $\mathrm{Zn}$ (ca. 15\%) and $\mathrm{Cu}$ (ca. 8\%) to a lesser extent (Table 4B). In pore-water, the same enrichments in $\mathrm{Fe}$ and $\mathrm{Ni}$ are observed. Correlation performed on 14 samples above Hekla $\mathrm{H} 3$ reveals a strong link between $\mathrm{Fe}, \mathrm{Ni}$ and loss on ignition (LOI) with $\mathrm{r}$ ranging from 0.85 between $\mathrm{LOI}$ and $\mathrm{Ni}$ to 0.95 between $\mathrm{Fe}$ and $\mathrm{Ni}$ (Fig. 6, Table 1). In addition, a second cluster of elements (Al, Mg, Si, Ti, K, Mg and $\mathrm{Sr}$ ) is recorded (see example of $\mathrm{Si}$ and $\mathrm{Al}$ in Fig. 6). These two groups of elements are clearly dependent on sediment mineralogy. On the one hand, the siliceous phase of the sediment is dominated by minerals and glass 
shards found in siliceous tephras, while on the other hand, the clustering of Fe, Ni and LOI implies the occurrence of a non-siliceous phase containing $\mathrm{Fe}$ and $\mathrm{Ni}$, which has a link with organic matter. The high correlation coefficient $(r=0.95)$ between $\mathrm{Fe}$ and $\mathrm{Ni}$ is in good agreement with the dissolved Fe migration from the upper layers to above H3 $(20-25 \mathrm{~cm})$ where it is blocked and precipitates. Indeed, H3 is a very compacted and very fine grained sized ash $(5-20 \mu \mathrm{m}$, see Section 5.1), and could possibly be a physical barrier to dissolved species migrating downwards through the water column. The high correlation coefficients found between $\mathrm{Fe}_{\mathrm{pw}}$, $\mathrm{Ca}_{\mathrm{pw}}, \mathrm{Mg}_{\mathrm{pw}}, \mathrm{Mn}_{\mathrm{pw}}, \mathrm{Ti}_{\mathrm{pw}}$, and $\mathrm{Ni}_{\mathrm{pw}}$, above $\mathrm{H} 3$ support the hypothesis of a tephra barrier. Therefore $\mathrm{H} 3$ not only stops water percolation, but concentrates dissolved elements $\left(\mathrm{Ca}_{\mathrm{pw}}, \mathrm{Fe}_{\mathrm{pw}}, \mathrm{Mg}_{\mathrm{pw}}, \mathrm{Mn}_{\mathrm{pw}}, \mathrm{Ti}_{\mathrm{pw}}\right.$, and to a lesser extent $\mathrm{Al}_{\mathrm{pw}}$ ) above the tephra. More specifically, $\mathrm{Fe}$ is blocked until its saturation, causing its precipitation and the subsequent adsorption of $\mathrm{Ni}$ onto freshly formed $\mathrm{Fe}$, poorly crystalline particles.

Fig. 3: Elemental profiles from ICE2. Concentrations are in $\mathrm{mg} / \mathrm{kg}$ for the solid phase and for anions in porewater, while in Ig/kg for cations in pore-water. Black circles are peat samples while open triangles are pore water samples.
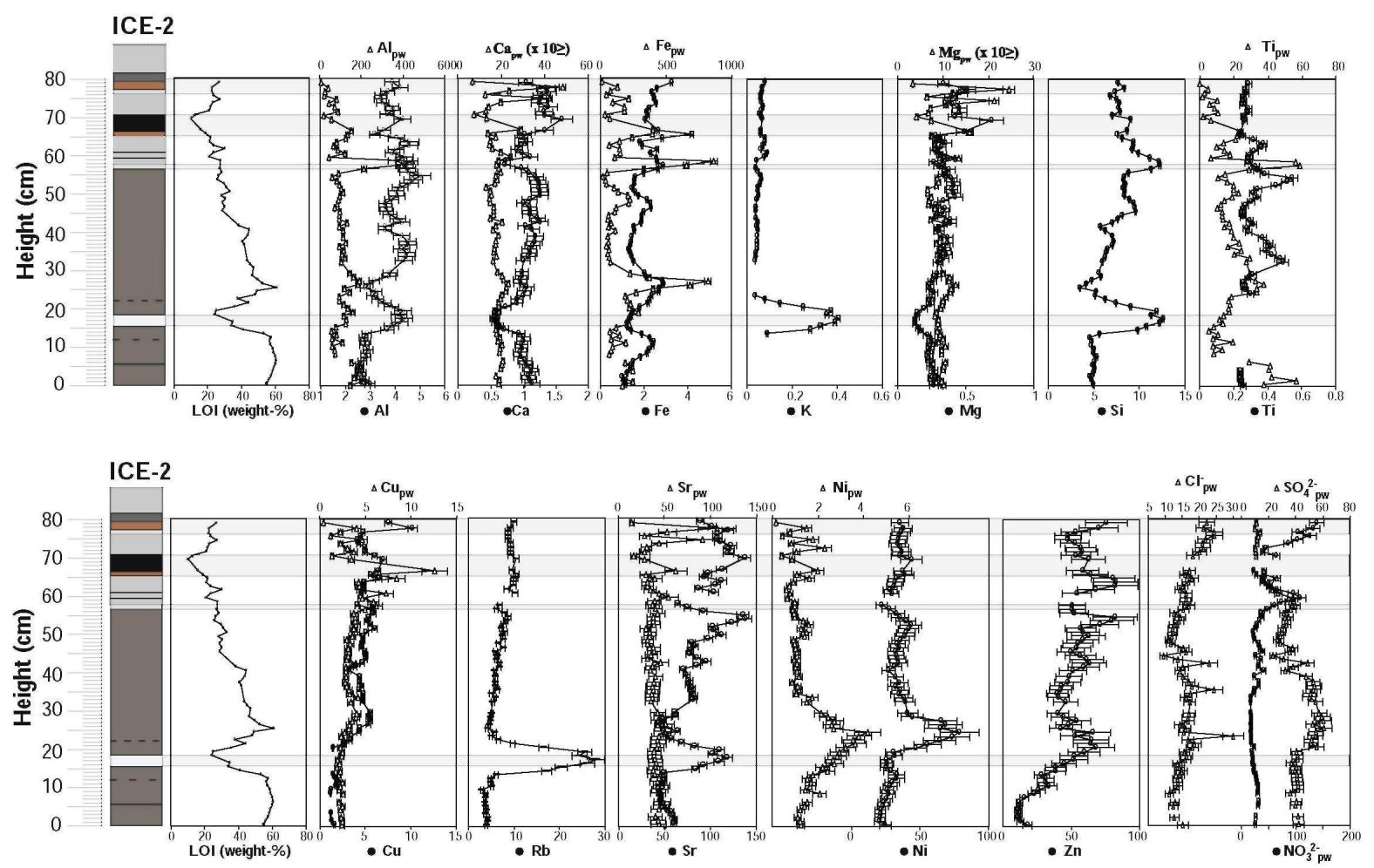

Table 3: Concentration of cations and anions in peat pore-water of ICE 2 peat outcrop measured by HR-ICPMS (MRAC, Tervuren) and Dionex $100(U L B)$, respectively. DL: under the detection limit. A dash means that the pore-water volume necessary for analyses was not obtained.

\begin{tabular}{|c|c|c|c|c|c|c|c|c|c|c|c|c|c|c|c|c|}
\hline $\begin{array}{l}\text { Depth } \\
\text { (cm) }\end{array}$ & $\begin{array}{l}\text { Al } \\
(\mu \mathrm{g} / \mathrm{kg})\end{array}$ & $\begin{array}{l}\mathrm{Ca} \\
(\mu \mathrm{g} / \mathrm{kg})\end{array}$ & $\begin{array}{l}\mathrm{Fe} \\
(\mu \mathrm{g} / \mathrm{kg})\end{array}$ & $\begin{array}{l}\text { Mg } \\
(\mu \mathrm{g} / \mathrm{kg})\end{array}$ & $\begin{array}{l}\text { Mn } \\
(\mu \mathrm{g} / \mathrm{kg})\end{array}$ & $\begin{array}{l}\text { Na } \\
(\mu \mathrm{g} / \mathrm{kg})\end{array}$ & $\begin{array}{l}\mathrm{Ti} \\
(\mu \mathrm{g} / \mathrm{kg})\end{array}$ & $\begin{array}{l}\text { Cd } \\
(\mu \mathrm{g} / \mathrm{kg})\end{array}$ & $\begin{array}{l}\mathrm{Cu} \\
(\mu \mathrm{g} / \mathrm{kg})\end{array}$ & $\begin{array}{l}\mathrm{Sr} \\
(\mu \mathrm{g} / \mathrm{kg})\end{array}$ & $\begin{array}{l}\mathrm{Pb} \\
(\mu \mathrm{g} / \mathrm{kg})\end{array}$ & $\begin{array}{l}\mathbf{N i} \\
(\mu \mathrm{g} / \mathrm{kg})\end{array}$ & $\begin{array}{l}\mathrm{Zn} \\
(\mu \mathrm{g} / \mathrm{kg})\end{array}$ & $\begin{array}{l}\mathrm{cl}^{-} \\
(\mu \mathrm{g} / \mathrm{kg})\end{array}$ & $\begin{array}{l}\mathrm{NO}_{3}^{-} \\
(\mu \mathrm{g} / \mathrm{kg}\end{array}$ & $\begin{array}{l}\mathrm{SO}_{4}{ }^{-2} \\
(\mu \mathrm{kg})\end{array}$ \\
\hline 0.5 & 146 & 18,883 & 172 & 10,033 & 2.252 & 14,823 & 38 & 0.050 & 2.414 & 44 & 0.958 & 1.240 & 5.13 & 14.45 & 25.07 & 42.15 \\
\hline 1.5 & 208 & & 251 & 526 & 3.38 & & 57 & & & 43 & & & DL & & & \\
\hline .5 & 164 & & 177 & 8779 & 3.0 & & 43 & 0.014 & & 40 & & & DI & & & 41.63 \\
\hline .5 & & - & - & - & - & & 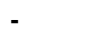 & - & & - & 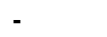 & & & - & & - \\
\hline 4.5 & 177 & 19,688 & 248 & 10,002 & 1.830 & 15,135 & 41 & 0.054 & 2.268 & 44 & 0.044 & 1.230 & 139.2 & - & & - \\
\hline .5 & $19^{-}$ & & 246 & & 2.6 & & 42 & & & 47 & & & DI & 11.88 & 30.12 & 39.76 \\
\hline 6.5 & 150 & 20,628 & 190 & 10,361 & 2.300 & 15,244 & 29 & 0.054 & 2.122 & 48 & 0.11 & 1.518 & 7.3 & 12.33 & 30.98 & 40.51 \\
\hline 7.5 & - & - & - & - & - & - & - & - & . & - & - & - & - & - & & - \\
\hline 8.5 & 72 & 19,077 & 70 & 9570 & 1.024 & 14,439 & 9 & 0.028 & 2.538 & 43 & 0.626 & 2.060 & 37.5 & 10.84 & 29.27 & 36.03 \\
\hline & 69 & & 87 & 9679 & & & 14 & & & 45 & & & DI & & & 41.68 \\
\hline 0.5 & 56 & & 95 & ,509 & & & 8 & & 2.2 & 47 & & 56 & D & 13.15 & 30.58 & 41.72 \\
\hline 1.5 & 108 & 18,409 & 198 & 9027 & 2.498 & 13, & 20 & 0.012 & 2.474 & 42 & & 1.682 & DL & 13.12 & 27.81 & 41.29 \\
\hline 2.5 & 58 & 19,474 & 84 & 9988 & 1.096 & & 8 & DL & 1.906 & 44 & & 1.512 & 6.51 & 12.96 & 26.98 & 40.78 \\
\hline 13.5 & 78 & 17,873 & 151 & 9327 & 2.612 & 14,337 & 11 & DL & 2.062 & 39 & 0.122 & 1.758 & DL & 13.53 & 25.29 & 40.64 \\
\hline
\end{tabular}




\begin{tabular}{|c|c|c|c|c|c|c|c|c|c|c|c|c|c|c|c|c|}
\hline 14.5 & 55 & 17,575 & 75 & 8652 & 1.370 & 14,176 & 6 & 0.012 & 2.230 & 38 & 0.174 & 2.396 & DL & 14.18 & 21.96 & 39.27 \\
\hline 15.5 & 75 & 19,185 & 124 & 9076 & 2.934 & 14,298 & 9 & 0.010 & 1.866 & 41 & 0.164 & 2.198 & DL & 13.52 & 22.71 & 40.37 \\
\hline 16.5 & 123 & 17,780 & 223 & 8801 & 4.496 & 14,283 & 14 & 0.010 & 2.178 & 41 & 0.082 & 2.724 & DL & 13.00 & 19.57 & 36.80 \\
\hline 17.5 & 125 & 17,351 & 214 & 8927 & 3.826 & 14,412 & 12 & 0.010 & 1.910 & 40 & 0.110 & 2.658 & DL & 15.08 & 20.61 & 41.40 \\
\hline 18.5 & 115 & 16,534 & 233 & 8153 & 4.698 & 14,522 & 14 & 0.010 & 2.364 & 39 & 0.218 & 2.840 & DL & 15.39 & 20.34 & 41.21 \\
\hline 19.5 & 158 & 16,839 & 294 & 8478 & 6.330 & 13,966 & 18 & 0.010 & 2.444 & 39 & 0.184 & 2.928 & 6.56 & 14.80 & 19.13 & 40.53 \\
\hline 20.5 & 134 & 18,832 & 221 & 9456 & 2.420 & 14,786 & 17 & 0.012 & 2.214 & 42 & 0.120 & 3.210 & DL & 16.95 & 22.85 & 55.13 \\
\hline 21.5 & 112 & 18,661 & 235 & 9779 & 3.124 & 14,762 & 18 & 0.010 & 2.600 & 44 & 0.152 & 3.612 & 5.88 & 17.55 & 18.16 & 51.18 \\
\hline 22.5 & 90 & 19,872 & 205 & 9978 & 2.770 & 14,237 & 17 & 0.020 & 2.664 & 43 & 0.130 & 3.528 & DL & 15.85 & 18.32 & 51.34 \\
\hline 23.5 & 90 & 20,305 & 193 & 10,595 & 1.154 & 14,154 & 19 & 0.010 & 2.306 & 44 & DL & 3.784 & DL & 27.93 & 18.26 & 54.29 \\
\hline 24.5 & 143 & 22,200 & 274 & 11,532 & 2.334 & 13,446 & 34 & 0.010 & 2.710 & 48 & 0.124 & 4.168 & $\mathrm{DL}$ & 14.65 & 16.82 & 54.82 \\
\hline 25.5 & 115 & 22,290 & 405 & 11,813 & 6.652 & 14,245 & 34 & 0.012 & 3.178 & 49 & 0.196 & 2.686 & 5.08 & 15.12 & 17.95 & 60.57 \\
\hline 26.5 & 183 & 23,453 & 686 & 12,694 & 8.888 & 13,733 & 38 & DL & 3.232 & 51 & 0.252 & 2.592 & DL & 13.60 & 16.49 & 52.58 \\
\hline 27.5 & 188 & 20,925 & 822 & 11,172 & 9.500 & 12,927 & 33 & DL & 3.592 & 44 & 0.188 & 2.716 & DL & 15.87 & 18.18 & 60.38 \\
\hline 28.5 & 160 & 20,295 & 375 & 11,431 & 4.382 & 13,599 & 29 & 0.010 & 3.908 & 48 & 0.126 & 2.422 & DL & 15.86 & 17.65 & 59.06 \\
\hline 29.5 & 142 & 18,226 & 231 & 9943 & 9.028 & 13,561 & 30 & DL & 4.008 & 43 & 1.036 & 2.120 & DL & 16.09 & 16.90 & 57.08 \\
\hline 32.5 & 99 & 16,259 & 78 & 9049 & 0.580 & 12,257 & 28 & 0.032 & 3.378 & 36 & 0.018 & 1.498 & DL & 16.30 & 16.35 & 54.46 \\
\hline 33.5 & 121 & 17,722 & 69 & 9343 & 1.932 & 12,884 & 30 & 0.042 & 4.154 & 37 & 0.336 & 1.748 & 17.03 & 15.30 & 17.25 & 50.01 \\
\hline 34.5 & 104 & 16,679 & 58 & 8699 & 1.412 & 12,760 & 21 & 0.012 & 3.242 & 36 & 0.274 & 1.026 & DL & 16.48 & 22.50 & 50.54 \\
\hline 35.5 & 114 & 16,820 & 69 & 9120 & 0.816 & 12,863 & 25 & 0.012 & 3.206 & 38 & 0.022 & 1.162 & DL & 22.83 & 23.36 & 52.91 \\
\hline 36.5 & 91 & 17,475 & 49 & 9306 & 1.146 & 14,097 & 17 & 0.012 & 2.930 & 37 & 0.430 & 1.108 & 66.3 & 16.86 & 30.95 & 53.66 \\
\hline 37.5 & 125 & 17,612 & 62 & 8488 & 1.138 & 13,798 & 24 & 0.010 & 2.802 & 38 & 0.192 & 0.854 & 14.7 & 16.07 & 31.78 & 52.61 \\
\hline 39.0 & 111 & 18,677 & 60 & 9423 & 0.768 & 13,783 & 20 & DL & 2.830 & 41 & 0.024 & 1.160 & 7.98 & 14.43 & 22.88 & 47.28 \\
\hline 40.5 & 111 & 16,090 & 115 & 8371 & 2.078 & 12,830 & 19 & 0.158 & 2.886 & 35 & 0.224 & 1.080 & 168 & 13.70 & 40.95 & 32.22 \\
\hline 41.5 & 91 & 17,512 & 65 & 8918 & 1.702 & 13,151 & 15 & 0.022 & 2.896 & 37 & 1.318 & 1.014 & 17.30 & 14.47 & 30.45 & 37.94 \\
\hline 42.5 & 129 & 20,438 & 83 & 10,278 & 1.808 & 14,683 & 18 & 0.018 & 3.924 & 46 & 0.256 & 1.076 & 6.29 & 21.53 & 31.53 & 48.52 \\
\hline 43.5 & 93 & 15,042 & 61 & 7236 & 1.074 & 12,482 & 14 & 0.046 & 2.940 & 31 & 0.064 & 0.940 & DL & 13.12 & 35.69 & 30.94 \\
\hline 44.5 & 91 & 16,495 & 65 & 8313 & 1.064 & 12,676 & 14 & DL & 3.068 & 36 & 0.104 & 1.076 & 75.63 & 9.27 & 25.12 & 23.15 \\
\hline 45.5 & 94 & 16,628 & 109 & 8580 & 2.906 & 12,976 & 14 & DL & 3.138 & 39 & 0.096 & 1.060 & 7.53 & 15.27 & 38.90 & 35.66 \\
\hline 46.5 & 70 & 16,569 & 123 & 8123 & 1.560 & 13,519 & 11 & 0.022 & 3.084 & 38 & 0.048 & 1.016 & 8.54 & 14.56 & 33.26 & 37.59 \\
\hline 47.5 & 83 & 14,853 & 217 & 6707 & 3.350 & 12,130 & 13 & 0.048 & 3.326 & 32 & 0.172 & 0.980 & DL & 11.17 & 30.90 & 28.28 \\
\hline 48.5 & 88 & 14,440 & 227 & 6914 & 2.984 & 11,778 & 15 & 0.020 & 2.962 & 32 & DL & 0.904 & DL & 10.67 & 23.81 & 26.34 \\
\hline 39.0 & 111 & 18,677 & 60 & 9423 & 0.768 & 13,783 & 20 & DL & 2.830 & 41 & 0.024 & 1.160 & 7.98 & 14.43 & 22.88 & 47.28 \\
\hline 49.5 & 95 & 15,452 & 211 & 7309 & 1.652 & 12,331 & 20 & DL & 3.576 & 34 & 0.026 & 1.396 & DL & 11.48 & 21.95 & 28.30 \\
\hline 50.5 & 109 & 15,028 & 138 & 6551 & 1.774 & 12,367 & 23 & DL & 3.926 & 34 & DL & 1.496 & 17.41 & 11.77 & 21.39 & 29.66 \\
\hline 51.5 & 100 & 13,073 & 107 & 6473 & 1.058 & 12,197 & 20 & $\mathrm{DL}$ & 3.674 & 30 & 0.084 & 1.234 & 11.03 & 11.72 & 25.34 & 29.88 \\
\hline 52.5 & 93 & 17,130 & 48 & 8527 & 0.354 & 13,209 & 20 & 0.028 & 3.966 & 39 & 0.034 & 1.576 & 14.29 & 12.03 & 27.72 & 33.10 \\
\hline 53.5 & 80 & 18,190 & 43 & 8995 & 0.268 & 14,346 & 17 & DL & 3.842 & 38 & DL & 1.348 & DL & 13.35 & 32.36 & 33.06 \\
\hline 54.5 & 57 & 17,482 & 22 & 8572 & 0.506 & 14,744 & 11 & DL & 3.852 & 38 & 0.048 & 0.976 & 6.37 & 13.79 & 38.48 & 34.58 \\
\hline 55.5 & 88 & 19,678 & 52 & 10,430 & 1.592 & 14,489 & 15 & DL & 3.744 & 43 & 0.212 & 0.944 & DL & 12.11 & 35.92 & 31.02 \\
\hline 56.5 & 212 & 18,891 & 334 & 10,083 & 0.582 & 14,507 & 30 & DL & 4.932 & 40 & 0.020 & 0.876 & DL & 14.59 & 47.44 & 36.31 \\
\hline 57.5 & 394 & 17,701 & 658 & 9570 & 1.202 & 14,835 & 59 & DL & 6.190 & 37 & 0.014 & 0.966 & 5.40 & 16.07 & 60.80 & 39.54 \\
\hline 58.5 & 448 & 18,806 & 868 & 9878 & 1.776 & 15,252 & 57 & DL & 5.884 & 39 & 0.036 & 0.984 & 40.89 & 15.13 & 73.54 & 35.96 \\
\hline 59.5 & 42 & 24,336 & 110 & 13,335 & 0.658 & 18,237 & 7 & DL & 4.662 & 55 & DL & 0.648 & 9.99 & 15.34 & 107.4 & 37.42 \\
\hline 60.5 & 121 & 19,802 & 152 & 9496 & 0.680 & 16,717 & 18 & 0.024 & 7.276 & 44 & DL & 0.772 & 18.37 & 15.30 & 95.57 & 26.87 \\
\hline 61.5 & 85 & 15,977 & 148 & 8642 & 0.878 & 14,799 & 15 & DL & 4.482 & 34 & DL & 0.596 & DL & 13.69 & 64.95 & 22.80 \\
\hline 62.5 & 64 & 14,750 & 72 & 8027 & 0.972 & 15,175 & 10 & DL & 4.324 & 32 & 0.040 & 0.724 & DL & 14.38 & 51.00 & 20.57 \\
\hline 63.5 & 78 & 14,996 & 147 & 8134 & 0.916 & 14,475 & 14 & 0.036 & 4.214 & 32 & DL & 0.916 & 10.27 & 15.93 & 38.16 & 19.27 \\
\hline 64.5 & 125 & 17,465 & 243 & 9191 & 1.624 & 16,547 & 22 & 0.014 & 8.412 & 40 & DL & 1.612 & 9.59 & 16.80 & 38.75 & 25.98 \\
\hline 65.5 & 132 & 13,813 & 400 & 7361 & 1.642 & 14,116 & 22 & DL & 5.974 & 30 & 0.018 & 1.068 & DL & 15.08 & 26.99 & 16.62 \\
\hline 66.5 & 151 & 29,056 & 405 & 15,763 & 2.780 & 30,083 & 25 & DL & 12.624 & 63 & 0.060 & 1.972 & 52.78 & 16.19 & 21.91 & 16.56 \\
\hline 69.5 & 52 & 13,206 & 75 & 7336 & 0.836 & 14,443 & 7 & 0.048 & 3.444 & 28 & 0.032 & 0.852 & 21.37 & - & - & - \\
\hline 70.5 & 17 & 7528 & 39 & 4127 & 0.934 & 7321 & 2 & DL & 1.290 & 17 & 0.100 & 0.404 & DL & 17.08 & 64.21 & 10.83 \\
\hline 71.5 & 86 & 12,960 & 184 & 6755 & 2.780 & 13,547 & 11 & DL & 3.702 & 28 & 0.246 & 1.034 & DL & 18.98 & 39.24 & 10.31 \\
\hline 72.5 & 69 & 14,156 & 184 & 7137 & 2.114 & 14,412 & 9 & DL & 2.990 & 31 & DL & 2.270 & 9.39 & 19.89 & 44.37 & 10.31 \\
\hline 73.5 & 43 & 19,885 & 98 & 10,593 & 1.152 & 16,698 & 6 & DL & 2.220 & 44 & 0.012 & 0.824 & 11.66 & 19.73 & 85.84 & 11.51 \\
\hline 74.5 & 78 & 42,205 & 220 & 21,125 & 1.728 & 32,859 & 11 & DL & 4.664 & 92 & DL & 1.772 & DL & 20.40 & 102.4 & 11.55 \\
\hline 75.5 & 18 & 12,689 & 46 & 6360 & 0.192 & 9422 & 2 & DL & 1.174 & 28 & DL & 0.440 & DL & 22.87 & 125.7 & 12.21 \\
\hline 76.5 & 21 & 23,721 & 79 & 12,294 & 0.322 & 17,292 & 3 & DL & 2.242 & 53 & DL & 0.760 & 6.36 & 22.83 & 103.4 & 13.44 \\
\hline 77.5 & 38 & 48,256 & 133 & 24,408 & 0.548 & 35,148 & 5 & DL & 4.036 & 107 & DL & 1.496 & DL & 19.96 & 131.7 & 9.71 \\
\hline
\end{tabular}

Table 4: (A) Calculation of metal release rate by $\mathrm{H} 3$ during the past $4 \mathrm{ka}$. (B) Calculation of concentration increase rates in the Fe peak above H3. See text for details.

\begin{tabular}{|c|c|c|c|c|c|c|c|c|c|c|c|c|c|}
\hline Al & $\mathbf{F e}$ & $\mathbf{K}$ & Mg & Mn & $\mathbf{C a}$ & $\mathbf{N a}$ & Si & $\mathbf{T i}$ & $\mathrm{Cu}$ & $\mathbf{R b}$ & $\mathrm{Sr}$ & $\mathbf{N i}$ & $\mathbf{Z n}$ \\
\hline $\begin{array}{l}\text { Mean concentration } 3.89 \\
\text { in fresh glass }\end{array}$ & 4.86 & 0.39 & 0.35 & 0.15 & 2.56 & 1.58 & 30.9 & 0.30 & - & - & - & - & - \\
\hline $\begin{array}{l}\text { Mean concentration } 3.85 \\
\text { in outcrop }(16.5 \mathrm{~cm} \\
\text { height })\end{array}$ & 1.22 & 0.39 & 0.13 & DL & 0.57 & DL & 12.1 & DL & DL & 25.8 & 110.4 & 25.9 & 44.3 \\
\hline $\begin{array}{l}\text { A. Release rate } 0.10 \\
\mathrm{mg} / \mathrm{kg} / \mathrm{yr}\end{array}$ & 9.10 & 1.03 & 0.55 & - & 4.97 & - & & 46.79 & - & - & - & - & - \\
\hline
\end{tabular}




\begin{tabular}{llllllllllllll}
$\begin{array}{l}\text { Mean concentration } 4.11 \\
\text { in natural peat (24.5- }\end{array}$ & 1.40 & - & 0.30 & - & 1.10 & DL & 6.35 & 0.41 & 4.41 & 6.55 & 79.0 & 34.9 & 44.1 \\
$\begin{array}{l}\mathbf{2 7 . 5} \text { cm height) } \\
\text { Mean concentration } 2.47\end{array}$ & 2.8 & 0.05 & 0.3 & & 1 & & 4.35 & 0.27 & 4.77 & 5.38 & 47.8 & 66.8 & 50.6 \\
in Fe peak (32.5-40.5 \\
$\begin{array}{l}\text { cm height) } \\
\begin{array}{l}\text { B. Enrichment factor }<0 \\
\text { above H3 }\end{array}\end{array}$ & 100 & - & 0 & - & $<0$ & - & $<0$ & $<0$ & 8.29 & $<0$ & $<0$ & 91.4 & 14.7 \\
\hline
\end{tabular}

Fig. 4: EDS elemental mapping of Veidivötn A.D. 1477 tephra showing compositional differences of glass shards (light grey in backscattered electron image and light green on the elemental mapping image) and the poorly crystalline Fe phases (dark grey on backscattered electron image and blue on the elemental mapping image).
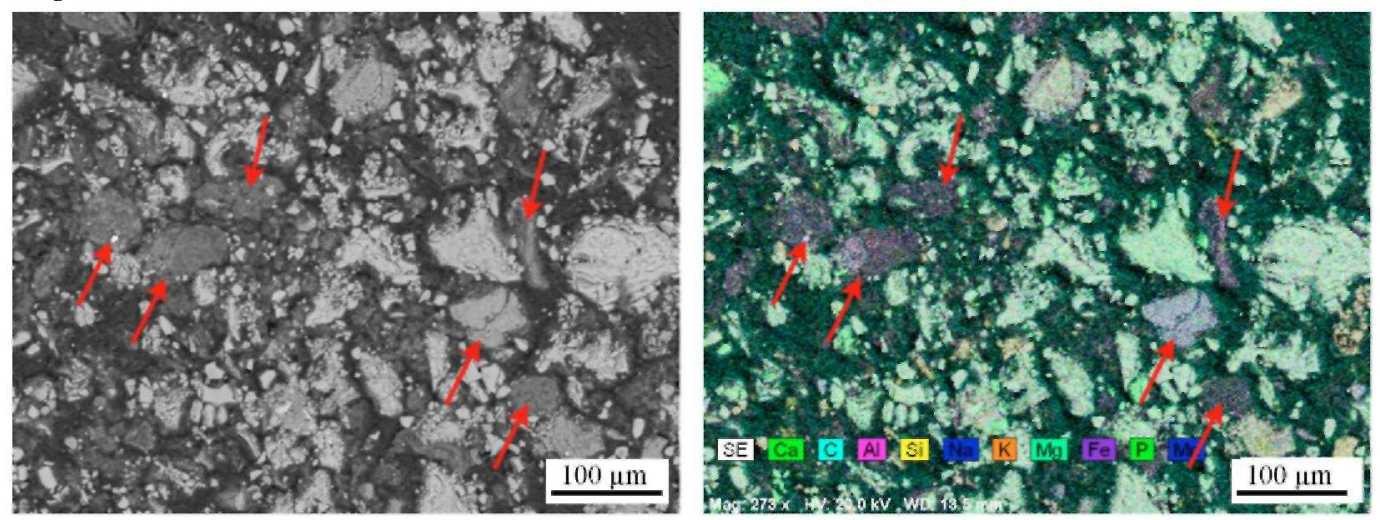

The behaviour of Ni seems dependent upon Fe and LOI. Above H3, there is a positive correlation between $\mathrm{Ni}$, $\mathrm{Fe}$ and LOI, but also with $\mathrm{Ni}$ in pore water. $\mathrm{Nickel}_{\mathrm{pw}}$ and $\mathrm{Fe}_{\mathrm{pw}}$ are moreover negatively correlated with a range of elements in the solid phase (i.e. $\mathrm{Al}, \mathrm{Ca}, \mathrm{K}, \mathrm{Mg}, \mathrm{Si}, \mathrm{Rb}, \mathrm{Sr}$ ). These latter elements are related to $\mathrm{H} 3$ particles, which were scattered in the peat during burial and slightly disturbed by vegetation growth. This demonstrates that $\mathrm{Ni}$ does not come from the dissolution of $\mathrm{H} 3$ particles reworked just above the H3 layer. Rather it is suggested that $\mathrm{Ni}$ is transported by water, which percolates through the peat and is consequently blocked by $\mathrm{H} 3$ and is possibly scavenged by $\mathrm{Fe}$ oxyhydroxide. It is also in agreement with the positive correlation between $\mathrm{Ni}$ and $\mathrm{Ca}_{\mathrm{pw}}, \mathrm{Fe}_{\mathrm{pw}}, \mathrm{Mg}_{\mathrm{pw}}, \mathrm{Mn}_{\mathrm{pw}}, \mathrm{Ti}_{\mathrm{pw}}$ and $\mathrm{Sr}_{\mathrm{pw}}$ (Table 3). Below $\mathrm{H} 3$ (Table 2), Ni is again well correlated with Fe ( $r$ $=0.8)$, but also with $\mathrm{Zn}(r=0.9)$. Though slightly enriched below H3, Ni is less concentrated than above. This feature leads to the hypothesis that $\mathrm{Ni}$ is more easily adsorbed on Fe-phases when organic matter is involved. This hypothesis is supported by previous studies, which showed that $\mathrm{Ni}$ was mainly scavenged by $\mathrm{Fe}$ oxyhydroxides (e.g. Xu et al., 2007; Gunsinger et al., 2006; Sterckeman et al., 2006; Dries et al., 2005; Hao et al., 2005; Stipp et al., 2002; Li et al., 2000). Nachtegaal and Sparks (2002) noted that this phenomenon was enhanced by the presence of humic acids. Grybos et al. (2007) also showed that Ni was adsorbed and/or coprecipitated on both Fe oxyhydroxides and organic matter. Nickel scavenging by amorphous Fe (III) oxides was recently experimentally demonstrated to occur at pH 6-7 (Xu et al., 2007).

EDS-SEM analyses of samples from the Fe rich layer above H3 suggest various compositions (Table 1). These particles are composed mainly of $\mathrm{Si}, \mathrm{Fe}$ and $\mathrm{Al}$. Iron content is variable. Moreover, one of the analysed particles has a low Fe content together with a low $\mathrm{C}$ content, suggesting the hypothesis that the behaviours of $\mathrm{Fe}$ and organic matter are linked. In thin section, a discontinuous cryptotephra occurs at this level (26 cm height, Fig. 1). However the $\mathrm{Mg}$ concentration profile is not affected by the scoria, compared to $\mathrm{Mg}$ concentrations in Veidivötn tephras. Likewise, Si displays lowest values (less than $4 \%$ at $26 \mathrm{~cm}$ height) of the profile, despite the presence of sparse basic scoria. It is, therefore, assumed that this discontinuous cryptotephra does not play a significant role on the geochemistry of the peat samples.

Below H3 $(0.5-13.5 \mathrm{~cm})$, LOI shows no relationship with chemical elements, for both the particles and the porewater (Table 2). Therefore organic matter does not play a significant role in the control of Fe, Ni and $\mathrm{Zn}$ behaviour. Silicon also does not show any relationship with the other elements. It displays a poor positive relationship with $\mathrm{K}(r=0.67)$, perhaps due to their association in glass particles from $\mathrm{H} 3$. Calcium, $\mathrm{Sr}$, Ti and 
$\mathrm{Mg}$ are correlated, but profiles show no variation in concentration. Calcium $\mathrm{pw}_{\mathrm{p}}, \mathrm{Mg}_{\mathrm{pw}}, \mathrm{Na}_{\mathrm{pw}}, \mathrm{Cu}_{\mathrm{pw}}, \mathrm{Sr}_{\mathrm{pw}}, \mathrm{Ni}_{\mathrm{pw}}$ display similar trends. Aluminium ${ }_{\mathrm{pw}}, \mathrm{Mn}_{\mathrm{pw}}, \mathrm{Ti}_{\mathrm{pw}}, \mathrm{Fe}_{\mathrm{pw}}$ also show flat profiles, although with small point to point variation, but no significant relationship can be pointed out.

Fig. 5: Fe oxihydroxide patches above H3. (A) General view showing large Fe patches in an organic mass. $(B, C)$ Zoom views on large patches showing that even the organic mass is strongly oxidised. (D) SEM backscattered electron view of a patch of Fe oxihydroxide showing typical cracked structure.
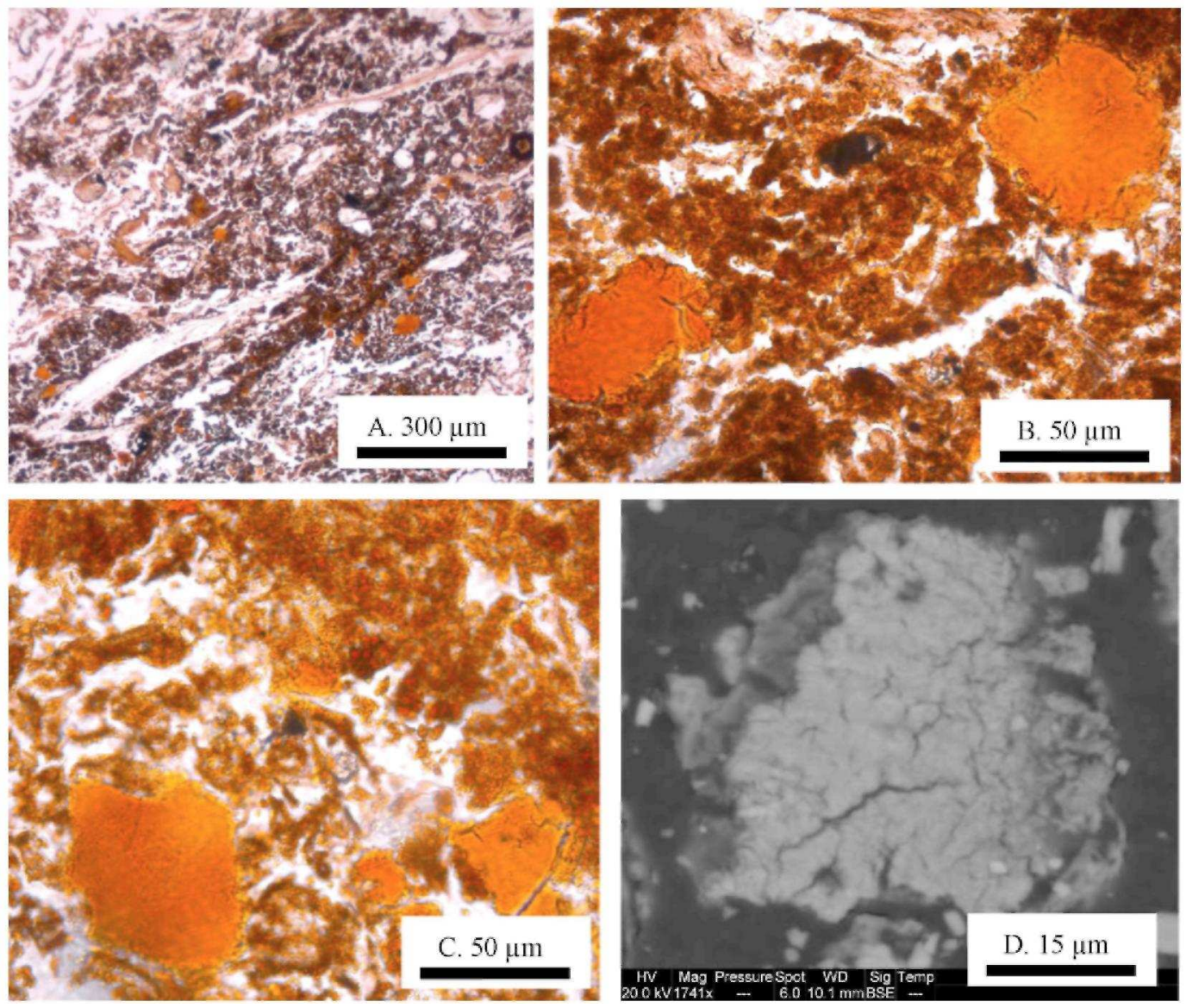

\subsection{Barrier efficiency}

From the Fe vs. depth profile, it appears that Fe concentrations are equal above and below H3. Iron pw $_{\text {is }}$ however, less concentrated below $\mathrm{H} 3$ than above, which favours the hypothesis of a semi-efficient water barrier that allows partial percolation of water. The occurrence of Fe in poorly crystalline phases in the middle of $\mathrm{H} 3$ pumice proves that even if most of the water is effectively retained above $\mathrm{H} 3$, some may have penetrated it. Iron in poorly crystalline phases could thus precipitate within the tephra, or just below, during the early phase of this process. Moreover, the permeability would limit its percolation and facilitate (1) solution stagnation in tephra porosity, (2) amorphous clay neo-synthesis and (3) bacterial activity. Indeed, the porosity created by the tephra is a confined space for bacterial growth fed by the nutrient release from tephra weathering $(\mathrm{K}, \mathrm{P})$ and by the dissolved organics (i.e. fulvic acids) in percolating water (Lehman et al., 2004). The development of bacterial communities partially reduces the porosity and usually forms a protective thin film on particles or forms real oncolithes (see Figs. 3-5 in De Vleeschouwer et al., 2008). This progressive reduction of porosity will confine Fe precipitation above the $\mathrm{H} 3$ tephra.

\section{Conclusions}

The geochemical investigation of an Icelandic peat profile containing tephra suggests that the principal tephra characteristics affecting the peat geochemistry are the grain size, thickness and, to a lesser extent, the tephra 
composition. A tephra having a sufficiently fine grain size (at least $<20 \mu \mathrm{m}$ ) and a sufficient thickness (at least $>1 \mathrm{~cm}$ ) can act as a capillary barrier to water percolation and elemental diffusion, creating Fe-, Ni-(and Zn-) enriched layers above. Furthermore, the confined space at the surface of the porous tephra fragments causes higher concentrations of iron and trace metals to accumulate, allowing the formation of Fe-organic bearing minerals. For example, in the investigated peat column, the H3 tephra acts like a barrier, Fe precipitates in the form of a Fe-amorphous phase above the tephra and scavenges Ni. Conversely, the coarser but thinner tephras encountered in the same outcrop do not act in the same way as the H3 deposit. The tephra composition seems to play a role in terms of elemental leaching. Basic tephras are more easily leached than acidic ones. However, this leaching can be slowed down by protective films formed around grains. Therefore, the amount of elements released from leaching is low compared to the concentrations encountered in such mineral-rich peat. More research should be directed to other peat bogs containing tephra deposits in order to precisely determine the minimum grain size/thickness ratio necessary to form an active barrier.

Fig. 6: Example of significant correlation in samples above H3 tephra.
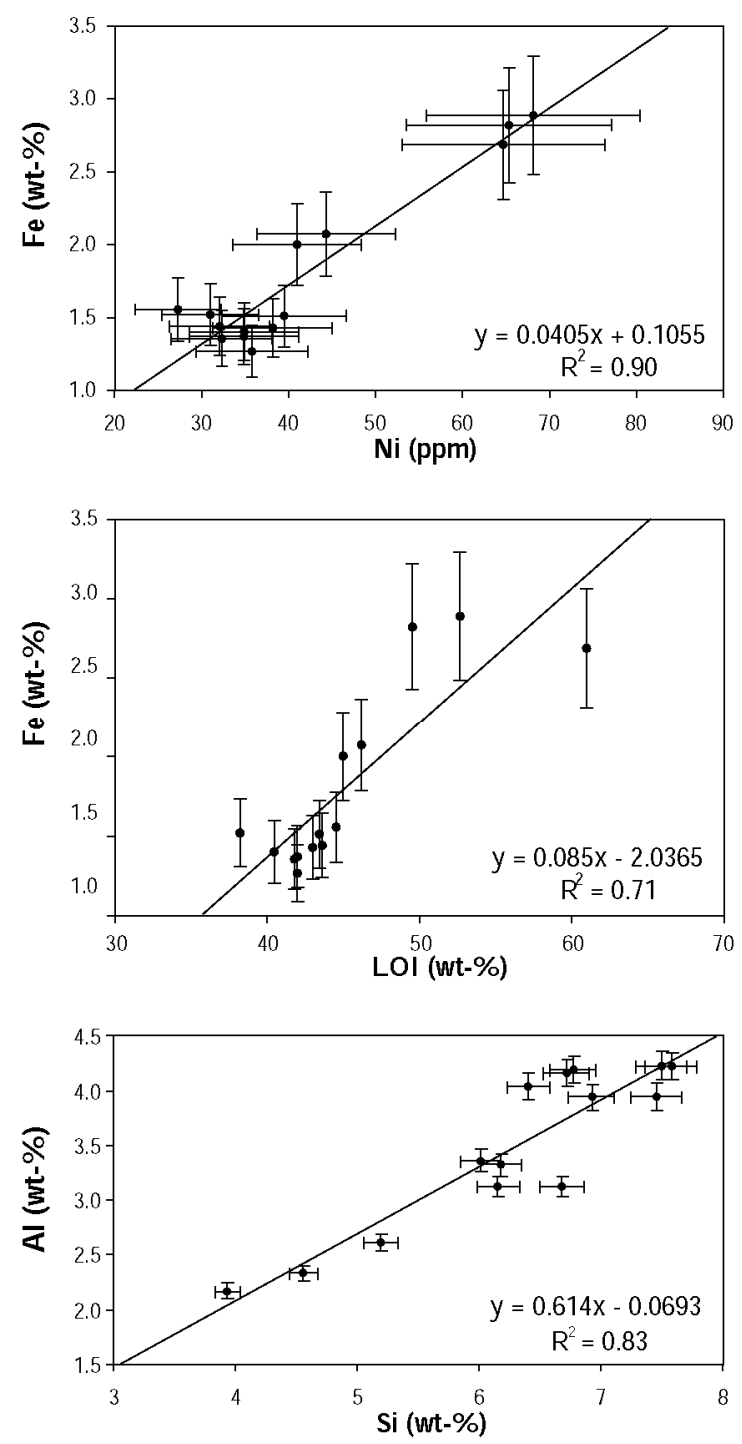

\section{Acknowledgements}

Xavier Boës and Jean-Paul Cullus were of great help in the thin section preparation. We also warmly thank Jacques Navez and Laurence Monin (MRAC Tervuren), and Philippe Recourt (UMR-PBDS, Lille, France) for their assistance with pore-water analysis and SEM-EDS analysis, respectively. Guy Bologne and Sophie 
Leclercq (LJRPGE, LJLg) were also very helpful during the calibration of the XRF. We are grateful to Maria Gehrels, Dmitri Mauquoy, Gunnar Mallon and Domenik Wolff-Boenisch for their comments and corrections to the English. We would like to finally acknowledge Morgan Jones, one anonymous reviewer and editor Ron Fuge for their high quality reviews and comments. The impregnation laboratory at LJRAP has been developed and optimised thanks to University fund Nr R.CERA.0438. This work is also supported by the French program IPROCI, funded by the Institut Paul Emile Victor (Iceland field mission and SEM-EDS analysis) and by NSRF (Belgian Scientific Research Foundation) credits. François De Vleeschouwer is supported by a FRIA fellowship.

\section{Appendix A}

Certified and measured values used for trace element XRF calibration. Concentrations in $\mathrm{mg} / \mathrm{kg}$. Accuracies and detection limits (DL) are also reported. Note that generally, accuracy decreases with the decrease of certified value concentrations. This feature is enhanced when reaching the detection limit.

\begin{tabular}{|c|c|c|c|c|c|c|c|}
\hline & & Recom & Measured & Error (\%) & Recom & Measured & Error (\%) \\
\hline & & \multicolumn{2}{|l|}{$\mathrm{Cu}$} & & \multicolumn{2}{|l|}{$\mathbf{P b}$} & \\
\hline CLB1 & Coal & 10 & 35 & 248 & $\overline{5.1}$ & 9 & 76.5 \\
\hline $1632 b$ & Coal & - & - & - & - & - & - \\
\hline NIES2 & Pond sediment & 210 & 206 & 2.1 & 105 & 94.8 & 9.7 \\
\hline NIES7 & Tea leaves & - & - & - & - & - & - \\
\hline NIES8 & Veh. part, exhaust & 67 & 65.9 & 1.6 & 219 & 225.6 & 3.0 \\
\hline JSD-2 & Sediment & 1114 & 1115 & 0.04 & 151 & 147 & 2.6 \\
\hline JSD3 & Sediment & 426 & 419.1 & 1.6 & 82 & 79.8 & 2.7 \\
\hline SGR & Sediment & 66 & 52.2 & 20.9 & 38 & 36.2 & 4.7 \\
\hline BCR 482 & Lichen & - & - & - & 40.9 & 45.4 & 11.0 \\
\hline BCR 100 & Beach leaves & - & - & - & 16.3 & 18.2 & 11.7 \\
\hline Mean & & & & 5 & & & 6 \\
\hline \multirow[t]{2}{*}{ Median } & & & & 5 & & & 6 \\
\hline & & \multicolumn{2}{|l|}{$\mathbf{R b}$} & & \multicolumn{2}{|l|}{$\mathrm{Ni}$} & \\
\hline CLB1 & Coal & 5.2 & 5.8 & 11.5 & 18 & 23.7 & 31.7 \\
\hline $1632 b$ & Coal & 5.05 & 5.4 & 6.9 & 6.1 & 9.4 & 54.1 \\
\hline NIES2 & Pond sediment & 42 & 39.6 & 5.7 & 40 & 37.2 & 7.0 \\
\hline NIES7 & Tea leaves & - & - & - & 6.5 & 3.6 & 44.6 \\
\hline NIES8 & Veh. part, exhaust & & & & 18.5 & 13.3 & 28.1 \\
\hline JSD-2 & Sediment & 27 & 25.9 & 4.1 & 94 & 93.5 & 0.5 \\
\hline JSD3 & Sediment & 285 & 287 & 0.7 & 19.6 & 25.3 & 29.1 \\
\hline SGR & Sediment & 83 & 76.2 & 8.2 & 29 & 25.8 & 11.0 \\
\hline BCR 482 & Lichen & - & - & - & 2.47 & 1.9 & 23.1 \\
\hline BCR 100 & beach leaves & - & - & - & - & - & - \\
\hline Mean & & & & 6 & & & 19 \\
\hline \multirow[t]{2}{*}{ Median } & & & & 6 & & & 19 \\
\hline & & \multicolumn{2}{|l|}{$\mathrm{Sr}$} & & \multicolumn{2}{|l|}{$\mathbf{Z n}$} & \\
\hline CLB1 & Coal & - & - & - & 48 & 73 & 52.1 \\
\hline $1632 b$ & Coal & - & - & - & 11.89 & 20.5 & 72.4 \\
\hline NIES2 & Pond sediment & 110 & 109.4 & 0.5 & 343 & 323.9 & 5.6 \\
\hline NIES7 & Tea leaves & - & - & - & 33 & 16 & 51.5 \\
\hline NIES8 & Veh. part, exhaust & 89 & 90.1 & 1.2 & 1040 & 1173.6 & 12.8 \\
\hline JSD-2 & Sediment & 202 & 228.8 & 13.3 & 2070 & 1992.8 & 3.7 \\
\hline JSD3 & Sediment & 60 & 57.6 & 4.0 & 139 & 123 & 11.5 \\
\hline SGR & Sediment & 420 & 403.2 & 4.0 & 74 & 54.9 & 25.8 \\
\hline BCR 482 & Lichen & - & - & - & 100.6 & 128.7 & 27.9 \\
\hline BCR 100 & beach leaves & - & - & - & - & - & - \\
\hline Mean & & & & 5 & & & 20 \\
\hline Median & & & & 5 & & & 20 \\
\hline
\end{tabular}




\section{Appendix B}

Analyses and statistics of five peat aliquots (PIS a-e), artificial mix (PISAM 0) and its progressive dilutions (PISAM 1-5) measured by ICP-AES. Concentrations are given in wt $\%$. Mean, standard deviation and reproducibility of PI-SAM samples are based on six runs. Medians are calculated from PISAM 1 to PISAM 4. PISAM 0 is not taken into account because it is not used in calibration lines. PISAM 5 is not used because it is too low. Values in bold were not taken into account for the calculation of median accuracy.

\begin{tabular}{|c|c|c|c|c|c|c|c|c|c|}
\hline & Al & $\mathbf{C a}$ & Fe & $\mathbf{K}$ & Mg & Mn & $\mathbf{N a}$ & $\mathbf{S i}$ & $\mathbf{T i}$ \\
\hline \multicolumn{10}{|l|}{ Peat } \\
\hline PIS a & 0.0464 & 0.5009 & 0.0493 & 0.0173 & 0.0478 & 0.0006 & 0.0102 & 0.0003 & 0.0029 \\
\hline PIS b & 0.0436 & 0.4687 & 0.0469 & 0.0162 & 0.0448 & 0.0006 & 0.0096 & 0.0007 & 0.0026 \\
\hline PIS c & 0.0462 & 0.5295 & 0.0496 & 0.0173 & 0.0481 & 0.0006 & 0.0103 & 0.0007 & 0.0029 \\
\hline PIS d & 0.0440 & 0.4691 & 0.0503 & 0.0167 & 0.0456 & 0.0006 & 0.0099 & - & 0.0028 \\
\hline PIS e & 0.0438 & 0.4777 & 0.0505 & 0.0167 & 0.0453 & 0.0006 & 0.0096 & - & 0.0029 \\
\hline Mean & 0.0448 & 0.4892 & 0.0493 & 0.0168 & 0.0464 & 0.0006 & 0.0099 & - & 0.0028 \\
\hline Stdev & 0.0014 & 0.0261 & 0.0014 & 0.0005 & 0.0015 & 0.0000 & 0.0003 & - & 0.0001 \\
\hline $\operatorname{Reprod}(\%)$ & 97 & 95 & 97 & 97 & 97 & 97 & 97 & - & 95 \\
\hline \multicolumn{10}{|l|}{ Artificial mix } \\
\hline \multicolumn{10}{|l|}{ Reference values } \\
\hline PISAM 0 & 6.172 & 1.819 & 8.668 & 0.342 & 0.622 & 0.047 & 2.189 & 19.002 & 0.526 \\
\hline PISAM 1 & 4.896 & 1.291 & 5.384 & 0.520 & 0.396 & 0.032 & 1.510 & 12.666 & 0.363 \\
\hline PISAM 2 & 3.368 & 1.071 & 3.767 & 0.207 & 0.308 & 0.020 & 1.006 & 8.441 & 0.228 \\
\hline PISAM 3 & 2.131 & 0.814 & 2.404 & 0.112 & 0.200 & 0.012 & 0.837 & 5.583 & 0.127 \\
\hline PISAM 4 & 1.434 & 0.724 & 1.703 & 0.117 & 0.146 & 0.008 & 0.336 & 3.652 & 0.103 \\
\hline PISAM 5 & 0.670 & 0.543 & 0.731 & 0.068 & 0.092 & 0.004 & 0.160 & 1.699 & 0.051 \\
\hline \multicolumn{10}{|l|}{ Mean concentration } \\
\hline PISAM 0 & 11.785 & 1.499 & 7.163 & 1.070 & 0.597 & 0.040 & 4.254 & 22.560 & 0.444 \\
\hline PISAM 1 & 4.979 & 1.455 & 5.916 & 0.547 & 0.427 & 0.031 & 1.571 & 12.904 & 0.385 \\
\hline PISAM 2 & 3.302 & 0.958 & 4.332 & 0.286 & 0.268 & 0.018 & 0.815 & 8.043 & 0.291 \\
\hline PISAM 3 & 1.801 & 0.786 & 2.942 & 0.081 & 0.185 & 0.011 & 0.289 & 5.411 & 0.111 \\
\hline PISAM 4 & 1.371 & 0.577 & 1.502 & 0.129 & 0.145 & 0.015 & 0.249 & 3.601 & 0.083 \\
\hline PISAM 5 & 1.202 & 0.800 & 0.105 & 0.115 & 0.122 & $\bullet 0.002$ & 0.228 & 2.217 & 0.051 \\
\hline \multicolumn{10}{|l|}{ Standard deviation } \\
\hline PISAM 0 & 0.8581 & 0.2019 & 0.7346 & 0.0731 & 0.0357 & 0.0003 & 0.2946 & 1.6007 & 0.0273 \\
\hline PISAM 1 & 0.0298 & 0.0216 & 0.0539 & 0.0375 & 0.0032 & 0.0008 & 0.0137 & 0.0194 & 0.0080 \\
\hline PISAM 2 & 0.0187 & 0.0173 & 0.0751 & 0.0212 & 0.0020 & 0.0019 & 0.0282 & 0.0370 & 0.0034 \\
\hline PISAM 3 & 0.0250 & 0.0098 & 0.0304 & 0.0241 & 0.0008 & 0.0011 & 0.0122 & 0.0507 & 0.0047 \\
\hline PISAM 4 & 0.0139 & 0.0092 & 0.0494 & 0.0240 & 0.0002 & 0.0006 & 0.0127 & 0.0184 & 0.0022 \\
\hline PISAM 5 & 0.0057 & 0.0178 & 0.0130 & 0.0040 & 0.0008 & 0.0008 & 0.0040 & 0.0277 & 0.0025 \\
\hline Median (PISAM 1-4) & 0.0219 & 0.0136 & 0.0517 & 0.0241 & 0.0014 & 0.0010 & 0.0132 & 0.0282 & 0.0041 \\
\hline \multicolumn{10}{|l|}{ Reproducibility } \\
\hline PISAM 0 & 93 & 87 & 90 & 93 & 94 & 99 & 93 & 93 & 94 \\
\hline PISAM 1 & 99 & 99 & 99 & 93 & 99 & 97 & 99 & 100 & 98 \\
\hline PISAM 2 & 99 & 98 & 98 & 93 & 99 & 90 & 97 & 100 & 99 \\
\hline PISAM 3 & 99 & 99 & 99 & 70 & 100 & 90 & 96 & 99 & 96 \\
\hline PISAM 4 & 99 & 98 & 97 & 81 & 100 & 96 & 95 & 99 & 97 \\
\hline PISAM 5 & 100 & 98 & 88 & 97 & 99 & 142 & 98 & 99 & 95 \\
\hline Median (PISAM 1-4) & 99 & 99 & 99 & 87 & 100 & 93 & 97 & 100 & 98 \\
\hline \multicolumn{10}{|l|}{ Accuracy } \\
\hline PISAM 0 & 91 & 18 & 17 & 213 & 4 & 14 & 94 & 19 & 16 \\
\hline PISAM 1 & 2 & 13 & 10 & 5 & 8 & 5 & 4 & 2 & 6 \\
\hline PISAM 2 & 2 & 11 & 15 & 38 & 13 & 8 & 19 & 5 & 28 \\
\hline PISAM 3 & 15 & 3 & 22 & 28 & 8 & 8 & 65 & 3 & 13 \\
\hline PISAM 4 & 4 & 20 & 12 & 11 & 1 & 83 & 26 & 1 & 20 \\
\hline PISAM 5 & 79 & 47 & 86 & 68 & 33 & 155 & 43 & 30 & 1 \\
\hline Median (PISAM 1-4) & 3 & 12 & 14 & 20 & 7 & 8 & 23 & 3 & 17 \\
\hline \multicolumn{10}{|l|}{ Mean DL } \\
\hline PISAM 1 & 0.9580 & 0.0434 & 0.1355 & 0.0322 & 0.1809 & 0.0412 & 1.3662 & 2.6116 & 0.5692 \\
\hline PISAM 2 & 0.7744 & 0.0449 & 0.1211 & 0.0344 & 0.1399 & 0.0432 & 1.0561 & 1.6954 & 0.4531 \\
\hline PISAM 3 & 0.6305 & 0.0471 & 0.1040 & 0.0367 & 0.1161 & 0.0391 & 0.8692 & 1.1785 & 0.2213 \\
\hline
\end{tabular}




\begin{tabular}{llllllllll} 
PISAM 4 & 0.5765 & 0.0503 & 0.0867 & 0.0451 & 0.1054 & 0.0457 & 0.7949 & 0.8191 & 0.2288 \\
PISAM 5 & 0.5613 & 0.0667 & 0.0755 & 0.0574 & 0.1049 & 0.0458 & 0.8326 & 0.5586 & 0.1701 \\
Median (PISAM 1-4) & 0.7025 & 0.0460 & 0.1126 & 0.0356 & 0.1280 & 0.0422 & 0.9627 & 1.4370 & 0.3410 \\
\hline
\end{tabular}

\section{Appendix C}

Autocorrelation performed above $\mathrm{H} 3$ tephra $(25.5-41.5 \mathrm{~cm}$ height). Positive correlation $>0.8$ are in bold, negative correlation $\mathrm{r}<0.8$ are in italics.

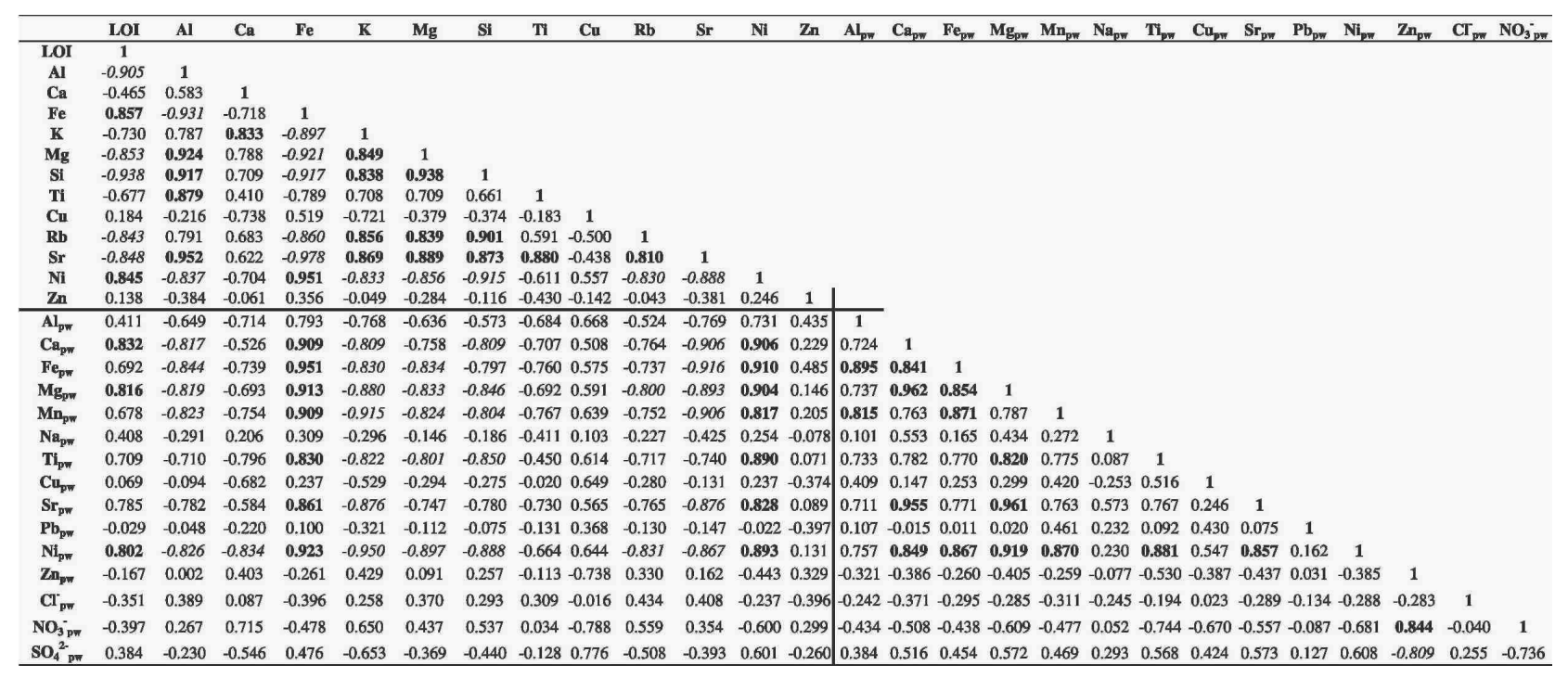

\section{Appendix D}

Autocorrelation performed below H3 tephra (0.5-13.5 cm depth). Positive correlation $>0.8$ are in bold, negative correlation $r<0.8$ are in italics.

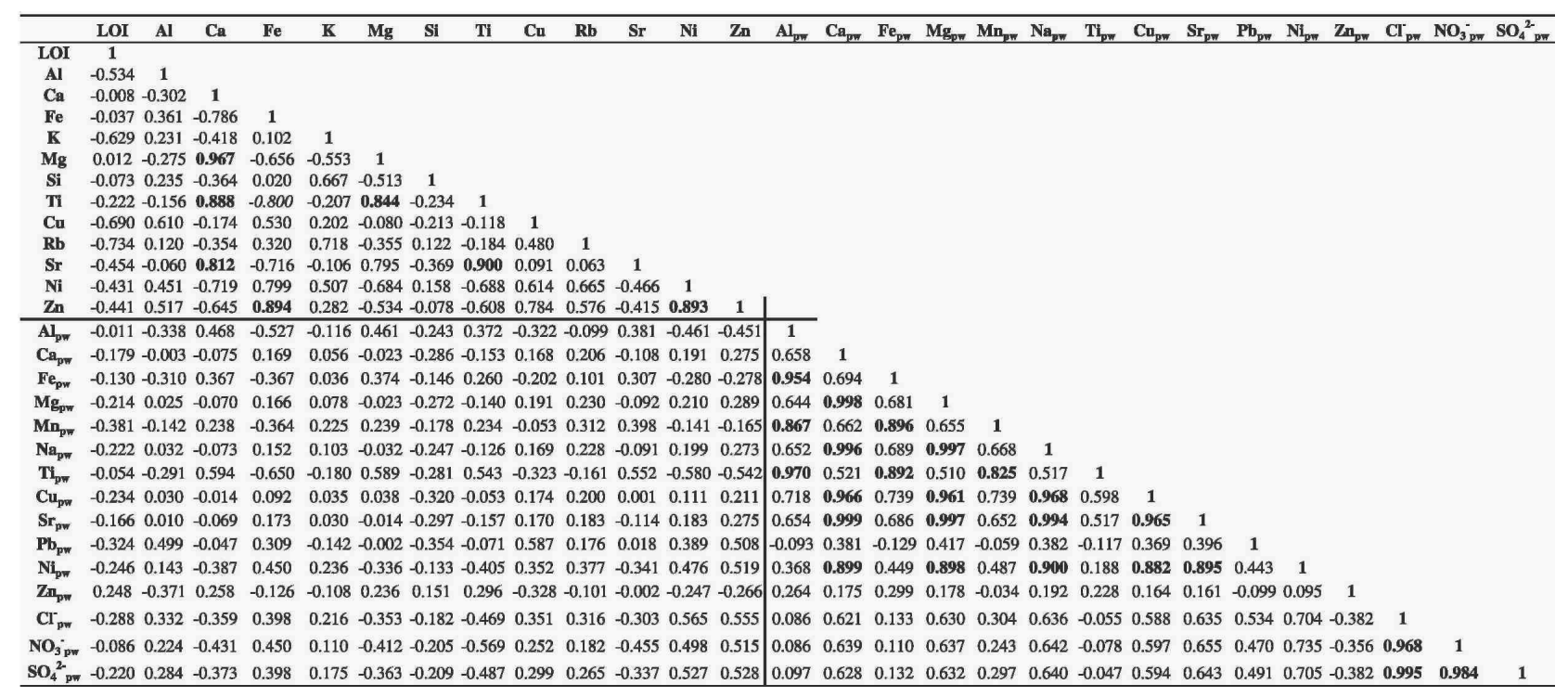




\section{Appendix E}

Autocorrelation performed below H1 158 tephra (41.5-58.5 cm depth). Positive correlation $>0.8$ are in bold, negative correlation $r<0.8$ are in italics.

\begin{tabular}{|c|c|c|c|c|c|c|c|c|c|c|c|c|c|c|c|c|c|c|c|c|c|c|c|c|c|c|c|}
\hline & Al & $\mathrm{Ca}$ & $\mathrm{Fe}$ & $\mathbf{K}$ & $\mathbf{M g}$ & Si & TI & $\mathrm{Cu}$ & $\mathbf{R b}$ & $\mathrm{Sr}$ & $\mathbf{N i}$ & $\mathrm{Zn}$ & $\mathbf{A l}_{\mathrm{pII}}$ & $\mathrm{Ca}_{\mathrm{pw}}$ & $\mathbf{F e}_{p w}$ & $\mathbf{M g}_{\mathrm{ow}}$ & $\mathbf{M n}_{\mathrm{pw}}$ & $\mathrm{Na}_{p w x}$ & $\mathbf{T i}_{p w}$ & $\mathrm{Cu}_{\mathrm{pw}}$ & $\mathrm{Sr}_{\mathrm{pm}}$ & $\mathbf{P} \mathbf{b}_{p r}$ & $\mathbf{N i}_{p w}$ & $\mathbf{Z n}_{\mathbf{p w}_{\mathrm{w}}}$ & $\mathrm{Cl}_{\mathrm{pur}}$ & $\mathrm{NO}_{3 \mathrm{pw}}^{-}$ & $\mathrm{SO}_{4}^{2}{ }_{\mathrm{pw}}$ \\
\hline $\begin{array}{l}\mathbf{A l} \\
\end{array}$ & 1 & & & & & & & & & & & & & & & & & & & & & & & & & & \\
\hline Ca & 0.166 & 1 & & & & & & & & & & & & & & & & & & & & & & & & & \\
\hline $\mathrm{Fe}$ & -0.168 & -0.837 & 1 & & & & & & & & & & & & & & & & & & & & & & & & \\
\hline $\mathbf{K}$ & 0.488 & 0.550 & -0.578 & 1 & & & & & & & & & & & & & & & & & & & & & & & \\
\hline $\mathbf{M g}$ & 0.527 & 0.826 & -0.620 & 0.662 & 1 & & & & & & & & & & & & & & & & & & & & & & \\
\hline $\mathrm{Si}$ & 0.093 & -0.752 & 0.846 & -0.366 & -0.402 & 1 & & & & & & & & & & & & & & & & & & & & & \\
\hline $\mathbf{T i}$ & 0.904 & 0.318 & -0.401 & 0.582 & 0.556 & -0.111 & 1 & & & & & & & & & & & & & & & & & & & & \\
\hline $\mathrm{Cu}$ & 0.300 & 0.658 & -0.438 & 0.149 & 0.634 & -0.401 & 0.330 & 1 & & & & & & & & & & & & & & & & & & & \\
\hline $\mathbf{R b}$ & 0.265 & 0.633 & -0.485 & 0.178 & 0.590 & -0.493 & 0.412 & 0.870 & 1 & & & & & & & & & & & & & & & & & & \\
\hline $\mathbf{S r}$ & 0.462 & 0.801 & -0.722 & 0.484 & 0.777 & -0.592 & 0.673 & 0.768 & 0.883 & 1 & & & & & & & & & & & & & & & & & \\
\hline $\mathbf{N i}$ & 0.122 & 0.865 & -0.703 & 0.296 & 0.716 & -0.651 & 0.314 & 0.858 & 0.889 & 0.894 & 1 & & & & & & & & & & & & & & & & \\
\hline $\mathbf{Z n}$ & 0.388 & 0.720 & -0.623 & 0.291 & 0.667 & -0.613 & 0.575 & 0.783 & 0.909 & 0.953 & 0.867 & 1 & & & & & & & & & & & & & & & \\
\hline$\overline{A l_{p}}$ & 0.070 & -0.834 & 0.712 & -0.303 & -0.496 & 0.773 & -0.178 & $3-0.715$ & -0.738 & $3-0.760$ & -0.866 & -0.748 & 1 & & & & & & & & & & & & & & \\
\hline $\mathrm{Ca}_{\mathrm{pw}}$ & 0.404 & -0.301 & 0.268 & 0.172 & -0.136 & 0.168 & 0.244 & -0.220 & -0.221 & -0.184 & -0.410 & -0.150 & 0.341 & 1 & & & & & & & & & & & & & \\
\hline $\mathrm{Fe}_{\mathrm{pw}}$ & -0.069 & -0.853 & 0.768 & -0.347 & -0.560 & 0.822 & -0.261 & -0.767 & -0.755 & -0.787 & -0.865 & -0.799 & 0.956 & 0.182 & 1 & & & & & & & & & & & & \\
\hline $\mathbf{M g}_{\mathrm{g}_{\mathrm{pm}}}$ & 0.386 & -0.430 & 0.366 & 0.092 & -0.225 & 0.280 & 0.185 & -0.229 & -0.284 & -0.287 & -0.492 & -0.245 & 0.446 & 0.966 & 0.278 & 1 & & & & & & & & & & & \\
\hline $\mathbf{M n}_{\mathrm{pw}}$ & -0.722 & -0.190 & 0.249 & -0.367 & -0.519 & 0.042 & -0.657 & -0.255 & -0.192 & -0.349 & -0.140 & -0.342 & -0.043 & -0.286 & 0.141 & -0.306 & 1 & & & & & & & & & & \\
\hline $\mathrm{Na}_{\mathrm{pw}}$ & 0.569 & -0.464 & 0.381 & 0.163 & -0.153 & 0.419 & 0.388 & -0.326 & -0.306 & -0.244 & -0.551 & -0.231 & 0.557 & 0.876 & 0.405 & 0.887 & -0.431 & 1 & & & & & & & & & \\
\hline $\mathrm{Ti}_{\mathrm{pww}}$ & 0.143 & -0.768 & 0.635 & -0.267 & -0.381 & 0.755 & -0.091 & -0.626 & -0.623 & -0.645 & -0.756 & -0.652 & 0.978 & 0.272 & 0.927 & 0.375 & -0.112 & 20.508 & 1 & & & & & & & & \\
\hline $\mathrm{Cu}_{\mathrm{pw}}$ & 0.415 & -0.674 & 0.597 & -0.139 & -0.216 & 0.776 & 0.166 & -0.456 & -0.482 & -0.467 & -0.660 & -0.493 & 0.904 & 0.439 & 0.825 & 0.512 & -0.278 & 80.691 & 0.933 & 1 & & & & & & & \\
\hline $\mathbf{S r}_{\mathrm{pw}}$ & 0.319 & -0.153 & 0.171 & 0.239 & -0.048 & 0.095 & 0.181 & -0.123 & -0.128 & -0.108 & -0.268 & -0.101 & 0.207 & 0.952 & 0.053 & 0.903 & -0.202 & 0.787 & 0.144 & 0.322 & 1 & & & & & & \\
\hline $\mathbf{P b}_{\mathrm{pw}}$ & -0.342 & -0.076 & -0.266 & 0.013 & -0.306 & -0.543 & -0.219 & -0.125 & 0.003 & -0.065 & -0.031 & 0.028 & -0.148 & 0.164 & -0.203 & 0.164 & 0.129 & -0.032 & -0.181 & -0.292 & 0.140 & 1 & & & & & \\
\hline $\mathrm{Ni}_{\mathrm{p}}$ & 0.178 & 0.568 & -0.612 & 0.398 & 0.629 & -0.277 & 0.333 & 0.212 & 0.274 & 0.496 & 0.509 & 0.338 & -0.246 & -0.226 & -0.276 & -0.323 & $3-0.300$ & $0-0.270$ & -0.097 & -0.064 & -0.113 & -0.168 & 1 & & & & \\
\hline $\mathrm{Zn}_{\mathrm{pw}}$ & -0.273 & -0.193 & -0.016 & -0.369 & -0.358 & 0.018 & -0.298 & -0.362 & -0.421 & -0.396 & -0.329 & -0.362 & 0.212 & 0.033 & 0.161 & 0.062 & -0.113 & $3-0.002$ & 0.160 & 0.046 & 0.023 & 0.072 & 20.054 & 1 & & & \\
\hline $\mathrm{Cr}_{\mathrm{pw}}$ & 0.136 & -0.190 & 0.250 & 0.160 & -0.052 & 0.091 & -0.034 & -0.262 & -0.221 & -0.211 & -0.315 & -0.133 & 0.353 & 0.644 & 0.215 & 0.616 & $5-0.027$ & 70.638 & 0.290 & 0.367 & 0.687 & 0.171 & $1-0.233$ & $3-0.237$ & 1 & & \\
\hline $\mathrm{NO}_{3 \mathrm{pw}}^{-}$ & 0.173 & -0.848 & 0.728 & -0.201 & -0.546 & 0.766 & -0.046 & $5-0.673$ & -0.723 & -0.721 & -0.901 & -0.685 & 0.887 & 0.495 & 0.831 & 0.599 & -0.091 & 10.733 & 0.813 & 0.809 & 0.351 & -0.114 & $4-0.464$ & 40.092 & 0.441 & 1 & \\
\hline $\mathrm{SO}_{4}{ }^{2-}$ & 0.171 & -0.208 & 0.222 & 0.201 & -0.045 & 0.081 & 0.036 & -0.225 & -0.152 & -0.160 & -0.272 & -0.085 & 0.333 & 0.662 & 0.187 & 0.640 & -0.116 & 60.668 & 0.289 & 0.382 & 0.709 & 0.258 & $8-0.181$ & $1-0.265$ & 0.972 & 20.433 & 1 \\
\hline
\end{tabular}

\section{References}

Blodau, C, Moore, T.R., 2002. Macroporosity affects water movement and pore water sampling in peat soils. Soil Sci. 167, 98-109.

Boës, X., Fagel, N., 2005. Impregnation method for detecting annual laminations in sediment cores: an overview. Sed. Geol. 179,185-194.

Boygle, J., 1999. Variability of tephra in lake and catchment sediments, Svinavatn, Iceland. Global Planet. Change 21, $129-149$.

Carboa, P., Kroma, M.D., Homokya, W.B., Benninga, L.G., Herutb, B., 2005. Impact of atmospheric deposition on N and P geochemistry in the southeastern Levantine basin. Deep Sea Res. Part II: Trop. Stud. Oceanogr. 52, 3041-3053.

Cornell, R.M., Giovanoli, R., Schneider, W., 1989. Review of the hydrolysis of iron (III) and the crystallization of amorphous iron (III) hydroxide hydrate. J. Chem. Technol. Biotechnol. 46, 115-134.

Daniels, R.E., Pearson, M.C., Ryden, B.E., 1977. A thermal-electric method for measuring lateral movement of water in peat. J. Ecol. 65, $839-846$.

De Vleeschouwer, F., Van Vliet-Lanoë, B., Fagel, N., Richter, T.O., Boës, X., 2008. High resolution petrography on resin-impregnated Holocene peat columns containing tephras. Principle, applications and perspectives. Quatern. Int. 178, 54-67.

Dries, J., Bastiaens, L, Springael, D., Kuypers, S., Agathos, S.N., Diels, L, 2005. Effect of humic acids on heavy metal removal by zerovalent iron in batch and continuous flow column systems. Water Res. 39, 3531-3540.

Eirfksson, J., Larsen, G., Knudsen, K., Heinemeier, J., Sfmonarson, L.A., 2004. Marine reservoir age variability and water mass distribution in the Iceland Sea. Quatern. Sci. Rev. 23, 2247-2268.

Flaathen, T.K., Gislason, S.R., 2007. The effect of volcanic eruptions on the chemistry of surface waters: the 1991 and 2000 eruptions of Mt. Hekla, Iceland. J. Volcan. Geotherm. Res. 164, 293-316.

Gislason, S.R., Oelkers, E., 2003. Mechanism, rates, and consequences of basaltic glass dissolution: II. An experimental study of the dissolution rates of basaltic glass as a function of $\mathrm{pH}$ and temperature. Geochim. Cosmochim. Acta 67, 3817-3832.

Glasauer, S., Langley, S., Beveridge, T.J., 2002. Intracellular iron minerals in a dissimilatory iron-reducing bacterium. Science 295, $117-119$.

Grybos, M., Davranche, M., Gruau, G., Petitjean, P., 2007. Is trace metal release in wetland soils controlled by organic matter mobility or Feoxyhydroxides reduction? J. Colloid Interface Sci. 314, 490-501.

Gunsinger, M.R., Ptacek, C.J., Blowes, D.W., Jambor, J.L., Moncur, M.C., 2006. Mechanisms controlling acid neutralization and metal mobility within a Ni-rich tailings impoundment. Appl. Geochem. 21, 1301-1321. 
Haeckel, M., van Beusekom, J., Wieser, M.G., König, I., 2001. The impact of the Mount Pinatubo tephra fallout on the geochemical environment of the deep-sea sediments in the South China Sea. Earth Planet. Sci.Lett. 193, 151-166.

Hao, Z.-W., Xu, X.-H., Jin, J., He, P., Liu, Y., Wang, D.-H., 2005. Simultaneous removal of nitrate and heavy metals by iron metal. J. Zhejiang Univ. Sci. 6, 307-310.

Hodder, A.P.W., De Lange, P.J., Lowe, D.J., 1991. Dissolution and depletion of ferromagnesian minerals from Holocene tephra layers in an acid bog. New Zealand, and implications for tephra correlation. J. Quatern. Sci. 6, 195-208.

Holmes, J., Hall, V., Wilson, P., 1999. Volcanoes and peat bogs. Geology Today, March-April, pp. 61-63.

Hotes, S., Poschold, P., Takahashi, H., Grootjans, A.P., Adema, E., 2004. Effects of tephra deposition on mire vegetation: a field experiment in Hokkaido, Japan. J. Ecol. 92, 624-634.

Jin, Z., Li, F., Cao, J., Wang, S., Yu, J., 2006. Geochemistry of Daihai Lake sediments. Inner Mongolia, north China: implications for provenance, sedimentary sorting, and catchment weathering. Geomorphology 80, 147-163.

Johnson, K.R., Hub, C, Belshawa, N.S., Hendersona, G.M., 2006. Seasonal trace-element and stable-isotope variations in a Chinese speleothem: The potential for high-resolution paleomonsoon reconstruction. Earth Planet. Sci. Lett. 244, 394-407.

Lacasse, C, 2001. Influence of climate variability on the atmospheric transport of Icelandic tephra in the subpolar North Atlantic. Global Planet. Change 29, 31-55.

Larsen, G., Thorarinsson, S., 1977. $\mathrm{H}_{4}$ and other acid Hekla tephra layers. Jökull 27, 27-46

Larsen, G., Dugmore, A., Newton, A., 1999. Geochemistry of historical-age silicic tephras in Iceland. Holocene 9, 463-471.

Larsen, G., Eirfksson, J., Knudsen, K.L., Heinemeier, J., 2002. Correlation of late Holocene terrestrial and marine tephra markers, north Iceland: implications for reservoir age changes. Polar Res. 21, 283-290.

Lehman, R.M., Baker, K.E., Mattson, E.D., 2004. Distribution of microorganisms and their activities in capillary barriers implications for modelling of hydrologic transport through capillary barriers.. Vadose Zone J. 3, 134-142.

Li, X., Wai, O.W.H., Li, Y.S., Coles, B.J., Ramsey, M.H., Thornton, I., 2000. Heavy metal distribution in sediment profiles of Pearl River estuary. South China. Appl. Geochem. 15, 567-581.

Lowe, D.J., Hunt, J.B., 2001. A summary of terminology used in tephra- related studies. Les Dossiers de l'Archeo-Logis 1, 17-22.

Nachtegaal, M., Sparks, D.L., 2002. Kinetics and mechanisms of nickel surface precipitation in multi-sorbent systems: a spectroscopic study. In: Proceedings of the 17th World Congress of Soil Science, August 14-21, 2002, Bangkok, Thailand.

Oelkers, E., 2001. General kinetics description of multioxide silicate mineral and glass dissolution. Geochim. Cosmochim. Acta 65, 3703-3719.

Pollard, A.M., Blockley, S.P.E., Ward, K.R., 2003. Chemical alteration of tephra in the depositional environment: theoretical stability modelling. J. Quatern. Sci. 18, 79-93.

Price, N.B., Karageorgis, A.P., Kaberi, H., Zeri, C, Krasakopoulou, E., Voutsinou-Taliadouri, F., Lindsay, F., Assimakopoulou, G., Pagou, K., 2005. Temporal and spatial variations in the geochemistry of major and minor particulate and selected dissolved elements of Thermaikos Gulf, Northwestern Aegean Sea. Cont. Shelf Res. 25, 2428-2455.

Sadler, J.P., Grattan, J.P., 1999. Volcanoes as agents of past environmental change. Global Planet. Change 21, 181-196.

Schmincke, H.-U., Park, C, Harms, E., 1999. Evolution and environmental impacts of the eruption of Laacher See Volcano (Germany) 12,900 a PB. Quatern. Internat. 61, 61-72.

Shotyk, W., 1993. Ion chromatography of organic-rich natural waters from peatlands. $\mathrm{I}^{-\mathrm{Cl}^{-}}, \mathrm{NO}_{2}^{-}, \mathrm{Br}^{-}, \mathrm{NO}_{3}^{-}, \mathrm{HPO}_{4}{ }^{2-}, \mathrm{SO}_{4}{ }^{2-}$ and oxalate. J. Chromatogr. 640, 309-316.

Soulier, A., 1995. Les formes solides du fer dans un sols hydromorphes, approche géochimique, micromorphologique et minéralogique. Ph.D. Thesis, Ecole Supérieure Agronomique de Rennes, Rennes, France.

Sparks, R.S.J., Bursik, M.I., Carey, S.C., Glaze, L., Gilbert, J.S., Woods, A.W., 1997. Volcanic plumes. John Wiley and Sons Inc., Hoboken, NJ, USA.

Steinmann, P., Shotyk, W., 1995. Ion chromatography of organic-rich natural waters from peatlands III. Improvements for measuring anions and cations. J. Chromatogr. A 706, 281-286. 
Sterckeman, T., Douay, F., Baize, D., Fourrier, H., Proix, N., Schwartz, C, 2006. Trace elements in soils developed in sedimentary materials from Northern France. Geoderma, 136: 912-929.

Stipp, S.L.S., Hansen, M., Kristensen, R., Hochella Jr., M.F., Bennedsen, L., Dideriksen, K., Balic-Zunic, T., Leonard, D., Mathieu, H.J., 2002. Behaviour of Fe-oxides relevant to contaminant uptake in the environment. Chem. Geol. 190, 321-337.

Techer, I., Advocat, T., Lancelot, J., Liotard, J.-M., 2001. Dissolution kinetics of basaltic glasses: control by solution chemistry and protective effect of the alteration film. Chem. Geol. 176, 235-263.

Thorarinsson, S., 1958. The Öraefajökull eruption of 1362. Acta Nat. Isl. 2, 1-99. Thorarinsson, S., 1967. The eruption of Hekla 1947-1948: I. The eruptions of Hekla in historical times. A Tephrochronological Study. Visindafelag Islendinga, Reykjavik, pp. 1-183.

Thorseth, I.H., Furnes, H., Tumyr, O., 1995. Textural and chemical effects of bacterial activity on basic glass: an experimental approach. Chem. Geol. 119, 139-160.

Todorova, S.G., Siegel, D.I., Costello, A.M., 2005. Microbial Fe(III) reduction in a minerotrophic wetland - geochemical controls and involvement in organic matter decomposition. Appl. Geochem. 20,1120-1130.

Warren, P.H., Ulff-Møllera, F., Hubera, H., Kallemeyna, G.W., 2006. Siderophile geochemistry of ureilites: a record of early stages of planetesimal core formation. Geochim. Cosmochim. Acta 70, 2104-2126.

Wastegärd, S., 2002. Early to middle Holocene silicic tephra horizons from Katla volcanic system, Iceland: new results from the Faroe Islands. J. Quatern. Sci. 17, 723-730.

Weiss, D., Shotyk, W., Rieley, Jack, Page, S., Gloor, M., Reese, S., Martinez-Cortizas, A., 2002. The geochemistry of major and selected trace elements in a forested peat bog, Kalimantan, SE Asia, and its implications for past atmospheric dust deposition. Geochim. Cosmochim. Acta 66, 2307-2323.

Wolff-Boenisch, D., Gislason, S.R., Oelkers, E., Putnis, C.V., 2004a. The dissolution rates of natural glasses as a function of their composition at $\mathrm{pH} 4$ and 106, and temperatures from 25 to $74^{\circ} \mathrm{C}$. Geochim. Cosmochim. Acta 68, 4843-4858.

Wolff-Boenisch, D., Gislason, S.R., Oelkers, E., Putnis, C.V., 2004b. The effect of fluoride on the dissolution rates of natural glasses at pH 4 and $25^{\circ} \mathrm{C}$. Geochim. Cosmochim. Acta 68, 4571-4582.

Woo, M.K., Young, K., 2006. High arctic wetlands: their occurrence, hydrological characteristics and sustainability. J. Hydrol. 320, $432-450$.

Xu, Y., Axe, L, Boonfueng, T., Tyson, T.A., Trivedi, P., Pandya, K., 2007. Ni(ll) complexation to amorphous hydrous ferric oxide: an X-ray absorption spectroscopy study. J. Colloid Interface Sci. 314, 10-17. 